\title{
Symbolic Politics or Generification ? The Ambivalent Implications of Tree Ordinations in the Thai Environmental Movement
}

Henry D. Delcore

Tree ordinations involve the adaptation of the Buddhist monk ordination ritual for use on trees. The practice of ordaining trees originated in northern Thailand in the late-1980s as a response to widespread deforestation from logging and the expansion of farmland. The first formally organized and public tree ordination ritual was apparently held by a monk named Phra Khru Manas in Phayao Province in 1988 (Montree et al. 1992; see also Darlington 1998, 2000; Isager and Ivarsson 2002). ${ }^{1}$ Phra Khru Manas, concerned about deforestation, reasoned that ordaining trees would help people see the value of forests and discourage logging by achieving a symbolic association between trees and monks. The practice soon spread to other provinces, including Nan, where I conducted field research in 1996 to 1998. A socially active monk from Nan named Phra Khru Phithak Nanthakhun traveled to Phayao in 1990 to visit Phra Khru Manas. He returned to Nan to hold the first tree ordination there in 1990, in his home village of Kiw Muang, followed by a larger ordination in 1991 with participation from ten different villages in Sanamchay District (see Darlington 1998). Since then, environmentalist monks, farmers, and NonGovernmental Organization (NGO) activists have held over twenty tree ordinations in Nan, as well as dozens in other provinces around Thailand (see for example Isager and Ivarsson 2002; Tannenbaum 2000). The rituals have aided in the conservation of ordained areas and bolstered the legitimacy of rural peoples' efforts to manage and conserve natural resources in the face of state preference for centralized control.

In this paper, I explore the political and cultural effects of tree ordinations by applying the concepts of "cultural objectification" and "cultural generification" (Handler 1984; Errington and Gewertz 2001; see below). I argue that recent uses of tree ordinations depend on a process of cultural objectification, facilitating the generification of the ritual and its various components as an example of the larger category of "local wisdom." I find significant forms of power difference implicated in the process. Middle class NGO activists largely controlled the practice and representation of the ritual and its symbols, and tended to objectify and simplify the values and practices of rural people. The tree ordinations of 1996-1997, dedicated to King Rama IX, had the further effect of symbolically bolstering the hierarchical structure of the Thai state and Thai society as a whole - a structure in which local leaders and middle class NGO activists exercise power as arbiters of "good" and "bad" culture among rural people. These are the ambiguous implications to which the title of this article refers: a process of objectification and generification and its place in the reproduction of a hierarchical political and cultural order, together with some decidedly positive outcomes of tree ordinations for the conservation and control of natural resources by rural people.

I intend to give tree ordinations and their organizers their due. The organizers of the rituals were generally well-intentioned advocates for rural people. But the rituals were also deeply implicated in the politics of culture in contemporary Thailand, and may even produce effects that run counter to the "grassroots" ethos of the organizers. I agree with Brosius (1999), who argues that anthropologists are well-positioned to stimulate parties to environmental debates to critically examine their tactics. He notes that because "essentialisms have historically been employed to perpetuate systems of inequality," they seem to draw the attention of anthropologists working in places where environmental issues are under debate (1999:280). An interest in the effects of essentialism in connection with the invocation of "local wisdom" does enliven this article. But I

1. The origin and history of tree ordinations is subject to conflicting interpretations. Montree et al. (1992:154) claim that "tree ordaining" is a "traditional" northern Thai ritual, a claim my own sources question. While, the practice of wrapping cloth around particularly large trees thought to house potent spirits is quite old the ritual performance of tree ordinations was apparently Phra Khru Manas' innovation. In the early 1990s, Phra Prajak Khuttajitto also performed tree ordinations in the Dongyai forest in Buriram Province, northeastern Thailand (see Taylor 1993). 
Henry D. Delcore

would like to characterize my hopes for this piece by borrowing the approach taken by Brian Morris in his study of religion. Like Morris, I find that the best approach is "neither one of reverence nor contempt, but rather an attitude of critical sympathy" (Morris 1987:4), which takes seriously those engaged in belief and action while also asking hard questions about motivation and meaning. I only hope that my critical sympathy towards tree ordinations contributes to an understanding of the politics of culture surrounding environmental issues among both scholars and those who are engaged on the ground in difficult struggles over rights and resources.

\section{Cultural Objectification and Generification}

Handler defines cultural objectification as "the imaginative embodiment of human realities in terms of a theoretical discourse based on the concept of culture" (Handler 1984:56; see also Handler 1988). According to Handler, Quebecois nationalism was based on the argument that the Quebecois have a distinct language, history, "cultural heritage," and national personality. The specification of content for each of these categories rested on a particular way of viewing culture. Culture must first be seen as a "thing" (in Handler's terms, a "natural object") with clear boundaries that has become "fixed" at some point in national history. Next comes a process of selection of certain supposedly representative cultural forms (e.g. items of material culture, dance styles, etc.), their placement in new contexts (e.g. in museums, as parts of a political campaign, etc.), and the construction of new meanings around them (as, for example, things which represent "Quebecois national culture") (Handler 1984:62-63). Handler argues that because the objectification process creates new meanings around cultural forms, objectification is a source of discontinuity. The resulting picture of the "culture" and its "contents" is "a construction grounded in the ideology of the present" $(1984: 62){ }^{2}$

Cultural objectification often occurs in contexts that provoke collective self-examination. In Handler's case, the context framing the objectification process was the struggle of the Parti Quebecois to maintain control of the provincial government and oversee a referendum on secession from Canada. Other cases - no less political - are more simply a matter of a group being confronted with a question that seems to demand an answer. For example, Handler takes the concept of "cultural objectification" from Bernard Cohn's work on the cultural effects of British rule in India (see Cohn 1987:224-254). British censuses required the recording of peoples' castes, forcing Indian census workers (who Cohn estimates numbered at least 500,000) to clarify - to themselves at least - just what caste was, and where the boundaries between different groups in fact lay. The census workers were thus confronted with "the question of who they were and what their social and cultural systems were" (Cohn 1987:248). Cohn argues that the censuses, among other events during the colonial period, pushed Indian intellectuals toward a new way of thinking about culture: "What had previously been embedded in a whole matrix of custom, ritual, religious symbol, a textually transmitted tradition, has now become something different. What had been unconscious now to some extent becomes conscious" (1987:229). The objectification process does not end there. Once "culture" in general, or some particular cultural category (such as "caste"), has been objectified, it becomes available for instrumental manipulation: "Aspects of the tradition can be selected, polished and reformulated for conscious ends" (Cohn 1987:229). ${ }^{3}$

What are the implications of cultural objectification in the contemporary world system ? Wilk (1995) proposes that a cultural effect of globalization is not the homogenization of the content of local cultures, but the increasing acceptance of uniform criteria, which Wilk calls "structures of common difference," by which differences are identified and expressed. According to Wilk, structures of common difference "celebrate particular kinds of diversity while submerging, deflating or suppressing others" (1995:118). Errington and Gewertz (2001) build on Wilk's

2. While I do not share Handler's commitment to a purely semiotic approach to culture, his insights can be applied to contexts marked by class and other forms of inequality that I see as shaping the objectification process (which is precisely the stance toward Quebecois nationalism urged by several of the comments attached to Handler's 1984 article).

3. In addition to cases directly related to the census, Cohn cites Gandhi's use of ahimsa for political ends as an example of the instrumental use of an objectified cultural form.

4. Wilk analyzes Belizean beauty contests, noting that they allow for the "safe" expression of

2

Vol. 112004

Journal of Political Ecology 
Symbolic Politics or Generification?

analysis by exploring the engagement of the Chambri with structures of common difference, resulting in the "generification" of their culture. As the Chambri engage in a process of cultural translation to make themselves comprehensible to others, the cultural particular becomes either "translated into the cultural general or into a general example of the cultural particular" (Errington and Gewertz 2001:510). For example, the Chambri have increasingly invoked their ancestral myths and associated ritual practices in struggles over resources such as land claims in court. However, in order to be at all comprehensible to non-Chambri, the very myths and practices which have been taken by Chambri to regulate the cosmos have now become "diluted to provide a not very demanding backdrop for people [who are] less concerned with maintaining the cosmos" than they are with pressing demands for rights to resources (Errington and Gewertz 2001:510). Rather than providing an encompassing and highly compelling framework for being in the world, Chambri myths and rituals have tended to become "situationally focused" and, in order to meet the demands of evidence operative in places like courtrooms, "formulaic and generic" (Errington and Gewertz 2001:510). ${ }^{5}$

Below, I apply the concepts of objectification and generification to the case of tree ordinations in Nan Province, in 1996-1997, after some background on the cultural politics of development and environmental issues in Thailand, and the crucial role of NGOs.

\section{Background: Environmentalism, Buddhism, and "Local Wisdom"}

Since the 1960s, the Thai state has pursued a resource intensive drive for national development, based on the extraction of natural resources, promotion of cash crops for export, and export-oriented industrialization (see Bello, Cunningham and Poh 1998; Dixon 1999; Muscat 1994; Pasuk and Baker 1998). Over the last four decades, the area of land cultivated in Thailand has increased rapidly, as farmers have moved into forested areas to expand fields for cash crops. In Nan Province, the crop of choice since the 1970s has been feed corn for export. As a result of the development choices made by successive governments as well as myriad farmers, the country now faces serious rural environmental problems (See Hirsch 1997a; Rigg 1995; Sponsel 1998). Thai forests have receded at a striking pace since the 1960s in the wake of logging concessions, illegal logging, and farmers' enthusiasm for clearing new fields. ${ }^{6}$ Results in many places include erosion,

ethnic difference in terms of expressive culture while ignoring the questions of land and labor rights which actually drive ethnic politics (1995:127-128). As pageants progress toward conclusion, even ethnic differences are dropped and the theme of national unity takes over. At that point, the focus further narrows to "essentialized biological characteristics" like age and gender, "beauty" and talent (Wilk 1995:128-129). By the time Miss Belize goes off to the Miss Universe pageant, she is certainly different from her counterparts from around the world, but different in a way that is easily intelligible on the global stage. The cost lies in the many forms of difference forms that are often critically important for the disempowered to pursue their interests - that have been submerged in the process of her selection.

5. In fact, the generification process at Chambri is part of longer term changes that are being witnessed and engaged by the Chambri, including labor migration and the emergence of new social categories such as "youth" (see Gewertz and Errington 1991; see also Gewertz and Errington 1999) Such changes which have provoked a fear among many Chambri that the detailed, esoteric, and sometimes secret ritual knowledge possessed by elders will not be effectively reproduced. In fact, the generification described by Errington and Gewertz (2001) were aimed by the Chambri at making themselves comprehensible to outsiders, as well as making myth and ritual more easily transmitted to succeeding generations.

6. In what is now Thailand, the proportion of land under forest has declined from an estimated $75 \%$ at the beginning of the twentieth century to about $26.7 \%$ in 1991 ; the decline between 1950 and 1991 was $59.3 \%$ to $26.7 \%$ (Dixon 1999:150, 179). These figures, however, overestimate the forest cover Thailand, in part because much land that has in fact been deforested is still officially classified as "forest land." By one account, between 1950 and 1991, farm holdings increased from $15.4 \%$ of land area to $41.6 \%$ (Dixon 1999:150). But this figure is probably also low. The Land Development Department put the percentage of land under cultivation in 1988 at 53\% (Dixon 
Henry D. Delcore

flooding, and landslides. In addition, many corn farmers in Nan have not met with riches from their new crop, but rather debt and degraded soils (see Delcore 2000).

Since the late-1980s, amid growing public awareness of the depth of the environmental challenges facing the country, the Thai state has become increasingly involved in reforestation efforts on national forest reserve land, national parks, and other categories of protected areas. Forest reserves are often occupied by rural people, though their customary claims to land are usually not recognized by law. Rather, in the eyes of the state, forest reserve land is managed and "conserved" by the Royal Forestry Department and other bureaucratic entities (see Peluso and Vandergeest 2001; Pinkaew 2001). Often, however, state "conservation" involves the resettlement of forest communities and/or razing of secondary growth so that land can be leased to private concerns to plant commercial tree crops like eucalyptus (see Carrere and Lohmann 1995:229-245; Lohmann 1991; Tegbaru 1997). Such resettlement-"reforestation" schemes were at the center of several large-scale protest actions by Thai NGOs and peoples' organizations (POs) during the 1980s and 1990s.

In this context, "grassroots environmentalism" has emerged as a form of Thai environmentalism dominated by rural POs and NGOs seeking to promote conservation while defending rural peoples' access to and management of natural resources (Hirsch 1997b). ${ }^{7}$ Grassroots environmentalism encompasses a range of practices and strategies in confronting the Thai state, ranging from the mass protest tactics of the Assembly of the Poor (AOP, a major Thai PO; see Missingham 2002) to the more accommodating style of the POs and NGOs of Nan Province. In Nan, monks like Phra Khru Phithak, together with Thai NGO workers and members of village-level farmer groups, focused on building alliances across the social spectrum, including monks, farmers, businesspeople, academics, and sympathetic state officials. After the tree ordinations of 1990 and 1991, Phra Khru Phithak, together with several local NGOs, founded a networking organization called Hak Muang Nan ("We Love Nan"; HMN). HMN sought to provide a forum for the exchange of ideas and coordination of activities among groups and individuals interested in sustainable development (kaan phatthana thii yang yuun) and environmental conservation (kaan anurak thammachat). By 1994 Nan had become well-known in Thai NGO circles as a model of cooperative, Buddhist-oriented conservation and development activism (one reason why I was drawn to Nan during an exploratory field visit that year).

Because HMN played a key role in organizing the tree ordinations of 1996-1997, a brief description of the organization is in order. HMN member organizations were divided into four sub-networks: monk organizations, NGOs, village organizations, and youth groups. The village organizations were further broken down into networks for groups focused on community forestry, river conservation, sustainable agriculture, community enterprise, and savings groups. By 1997, the number of HMN member organizations in all four sub-networks had grown to 62. In 1994, HMN secured major funding from the German Development Service for the maintenance of an office and several paid staff members. The network has added other foreign and domestic funding sources since then, including Thai state funding for certain health and education-related projects. In 1996-98, Phra Khru Phithak was the Chairman of HMN. In theory, the organization's direction was set by a Governing Committee with representatives from all the sub-networks; in practice, the day-to-day business of HMN was conducted by the full time staff which was drawn, by group consensus, from among the NGO activists whose organizations belonged to HMN. A few NGO

1999:157, 183).

7. Hirsch rightly points out that Thai environmentalism as a whole is diverse, including the state's technocratic approach based on central control of natural resources, urban middle class activism on issues such as traffic jams and water and air pollution, and the work of rural POs and NGOs on questions such as land rights and deforestation (see Hirsch 1997a and 1997b). Thai environmental NGOs run the gamut from those hostile to human occupancy of any area deemed to be environmentally sensitive to the grassroots environmentalist strain defined above, which was dominant in Nan Province. I take Hirsch's use of the term "grassroots environmentalism" to be a technical label for a form of Thai environmentalism and not an unreflective application of the term "grassroots" as simply meaning "from the people."

8. HMN generally did not fund projects within the network, but rather assisted member organizations in finding funding.

4

Vol. 112004

Journal of Political Ecology 
Symbolic Politics or Generification?

activists who were particularly close to Phra Khru exerted a good deal of influence over the organization, and used their connections with the larger Thai NGO movement to bring in funding and activities. Sympathetic state officials, scholars, and other individuals not affiliated with NGOs exerted influence through the group's Advisory Board and a few were part of an inner circle of NGO workers and village leaders that revolved around Phra Khru Phithak. ${ }^{9}$

During my fieldwork in Nan, there were five small-scale NGOs in the HMN network. They were established and run by Nan natives, staffed by two to five full time activists, with mostly foreign funding. A sixth larger organization drew some personnel from other provinces, but was headed and heavily staffed by local people..$^{10}$ By 1996, Nan's NGOs were involved in the full breadth of rural development activities, such as education, child care, youth groups, savings groups, health (including drug abuse and AIDS prevention), community forestry and river conservation, and sustainable agriculture. Altogether, full-time salaried NGO workers in Nan numbered about twenty-five in 1997, with equal numbers of men and women (though the handful of senior NGOs workers was mostly male). Almost all of the village groups in the HMN network were located in villages participating in NGO projects.

NGOs in Nan were distinguished from other Thai NGOs in that the activists were natives of the province in which they worked. In fact, many Nan NGO workers were active in their villages and districts of birth. They were, however, distinct from their rural friends and kin in that many had pursued higher education outside of Nan Province and had personal histories of association with the larger Thai NGO movement. They had acquired many of the distinct Thai NGO ways of framing rural development issues, particularly a commitment to the "community culture" (watthanatham chumchon) concept. "Community culture" refers to a traditional Thai "village culture" based on connection with nature, physical labor, and relations of mutual aid between community members. According to its adherents in some Thai NGOs and other segments of the middle class, "community culture" was an autonomous system of administration, economics, and beliefs that has come under assault from the "imported" capitalist culture favored by Thai state development policy (for various perspectives on the "community culture" concept, including some critical commentary, see Chatthip 1991; Delcore 2003; Hewison and Phongphit 2001; Kitahara 1996; Pasuk 1999; C. Reynolds 1998:138-140). The ideas associated with "community culture" lie behind many of the "sustainable development" and "local development" initiatives promoted by small-scale, indigenous Thai NGOs, who often seek to shield "community culture" and "local wisdom" (phuumpanya chaaw baan; literally, "villagers' wisdom," the Thai gloss on "indigenous knowledge") from destruction by mitigating the impact of capitalist development and state intervention on rural communities.

Under the HMN umbrella, Phra Khru and his closest allies were committed to seeking effective ways to press their issues without alienating allies (such as state officials) who were hostile to a confrontational, mass protest strategy. Phra Khru and most local NGO activists argued that progress on contentious issues like local resource control was best achieved through cooperative alliance building, and they have put much effort into developing culturally acceptable forms of environmentalist expression. Tree ordinations, because they invoke the practice of Buddhism, the national religion, have thus become an important practice of grassroots environmentalists in Nan. ${ }^{11}$

9. Despite the strong NGO influence within HMN, senior monk, village, and NGO leaders eschewed the label "NGO" for HMN itself. In part, their reluctance to take on the "NGO" label was a political choice. In Thailand, "NGO" can carry connotations of foreign-influence, or the "meddling" of outsiders (both foreign and Thai) in rural areas where state officials typically claim sovereignty. Aware of the deauthorizing strategies of their opponents, HMN's leaders struggled to characterize their organization as a "peoples' organization" (ongkon prachaachon) or "cooperative organization" (ongkon ruam muu).

10. All of the NGOs traced their roots back to the early 1990s, when transnational and national development initiatives opened up funding opportunities for small-scale NGOs (see Delcore 2000 for a more detailed history of NGO activism in Nan; see also Delcore 2003).

11. Importantly, however, the use of tree ordinations for conservation was more than a mere tactic for grassroots environmentalists in Nan. "Santiwiithii" was a term I heard often in Nan in 1996-98. It roughly translates as "peace method," and I take it to refer to a kind of Thai Buddhist 
Henry D. Delcore

The fusion of Buddhism and environmentalism in Nan fits with a broader tendency in Thai grassroots environmentalist circles to claim Buddhism as an inherently conservationist religion. While the doctrinal debates about this claim are beyond the scope of this article, ${ }^{12}$ elements of Buddhism are in fact part of the Thai environmentalist scene, and tree ordinations are one expression of Thai "eco-Buddhism." Major thinkers in Thai Buddhist environmentalism include monks like Buddhadasa Bhikkhu and Dhammapitaka, and laypeople like Sulak Sivaraksa (see for example Sulak 1990a, 1990b). Buddhadasa Bhikkhu came to conservationist conclusions through his identification of the dhamma with nature. He also employed the concept of interdependent coarising to stress the interconnection of all things. In his analysis of Buddhist ethics, he argues that loving-kindness is the correct Buddhist attitude to all forms of life (Taylor 1993:4), and lovingkindness together with gratitude are the keys to a moderate approach to nature (on Buddhadasa and Dhammapitaka, see Jackson 1988; Swearer 1997).

The arguments advanced by such monk-scholars and learned laypeople have converged with the work of village-level monks, local leaders, and NGO workers who are on the frontlines of grassroots environmentalism in Thailand: "ecology monks" like Phra Ajaan Pongsak (see Suchira 1992), Phra Prajak (see Taylor 1993, 1996) Phra Khru Phithak (see Darlington 1997, 1998; Delcore 2000), and conservationist laypeople in places like Nan. For example, one common argument, advanced by some ecology monks, refers directly to the Buddhist value of loving kindness to exhort people to minimize the suffering they inflict on other living things. In this same vein, they argue that environmental degradation, once in motion, increases the suffering of rural people (by depriving them of the means for pursuing their livelihood, for example), and must therefore be addressed out of compassion for the people who suffer. Ultimately, ecology monks argue that environmental degradation has its roots in greed and ignorance, which they seek to replace with the Buddhist values of detachment and moderation. Another common argument involves the observation that the Buddha's various incarnations revolved around the forest and nature, and significant events in the life of Siddhartha Gotama occurred in forests. The Buddha often expressed empathy for nature, encouraged planting trees as monastic settings, and taught that natural settings are appropriate places to pursue enlightenment (Sponsel and Natadecha-Sponsel (1997 and 2002) and Swearer (1998) elaborate on several of these lines of argument). The rules of discipline for monks also contain many specific directives limiting their impact on the environment (see Sponsel and Natadecha-Sponsel 2002).

In general, Thai grassroots environmentalists do not explicitly talk of Buddhism as a component of local wisdom. When local wisdom is invoked within NGO circles to refer to the religious beliefs and practices of Tai-speaking peoples, it most commonly refers to spirit beliefs

version of Gandhi's satyagraha. I found that activists in Nan invoked the term to characterize their own approach to advocacy in contrast to the confrontational strategy of the Assembly of the Poor, which held mass protests in Bangkok during spring, 1997. Activists in Nan refused to criticize the AOP's choice of strategy (some even credited the AOP with following satiwiithii themselves), noting that the history and issues of the northeast were different from the situation in the north. Still, I sensed that their invocation of the "peace method" as a foundation for HMN represented their attempt to distinguish themselves from the AOP and thus avoid political sanctions from their more conservative local allies (and opponents).

12. Any discussion of the conservationist character of Buddhism must start from an appreciation for the regional and historical diversity within Buddhism, as well as the crucial distinction between the textual tradition and the actual practices of Buddhists themselves. Sponsel and Natadecha-Sponsel (1993, 1995, 1997, and 2002) and Swearer (1997, 1998, and 2001) are among those who agree that there is a strong concordance between core Buddhist doctrines and the values and practices that support sustainable interactions with nature. These scholars are also students of Thailand and Thai Buddhism, and their work draws on both Theravada doctrine and the Buddhism-based environmentalism of some Thai monks and laypeople. Harris (1991, 1995), on the other hand, is a well-known critic of the "eco-Buddhist" position, basing his analysis on the textual tradition of the suttas. Some of Harris' points are addressed briefly by Swearer (1997:37-40) and Sponsel and Natadecha-Sponsel (2002). See also Eckel (1997) for a cogent discussion of what a Buddhist philosophy of nature might look like, taking into account the history of the religion through several major historical periods and regions. 
Symbolic Politics or Generification?

said to have ecological benefits, such as beliefs in powerful spirits that inhabit watershed forests and inhibit logging in those areas. However, I argue that the practice of tree ordinations has been interpreted by activists in Nan in ways consistent with the idea of local wisdom. First, the monk and NGO organizers of the rituals stressed that the ordinations were an expression of rural peoples' dependence on and respect for nature, evoking an image of tree ordinations as a practice welling up from the "community culture" of rural people. ${ }^{13}$ Second, NGO leaders in Nan tended to justify their nonconfrontational strategy as based on what they saw as a form of political praxis particular to rural Thais. Some NGO workers in Nan were explicitly critical of large-scale confrontations with the state because they argued that formal organizations and explicit confrontations presented the powerful with a clear target to suppress. ${ }^{14}$ One NGO leader argued to me that villagers in places like Nan had their own form of politics, one that did not seek to challenge the "larger power structure" (khroong saang amnaat yay). He argued that from the time of democratic transition in Thailand in the late-1980s, villagers had largely kept themselves removed from the system of political parties and elections, which was rife with money politics and vote buying. Instead, they pursued their interests through practices like tree ordinations - which he called a kind of "symbolic politics" (using the English term). Symbolic politics, he argued, was a way to draw in middle class allies and pressure elites to see the value of local efforts. This form of politics, he argued, was not a matter of seizing power at the top, but rather one of seeking "horizontal" linkages.

In practice, then, the NGO activists in Nan connected tree ordinations with the idea of "local wisdom," a Thai variant of "indigenous knowledge" (IK). This connection to the global discourse on IK is relevant to the process of objectification and generification. The concept of IK has much to recommend it as a tool for increasing our understanding of the world, and in the hands of advocates pressing what are often important cases and issues. IK underscores the fact that the subjects of development do have something to teach "the experts" about local environments, and that the very "needs" addressed by any development scheme are culturally constituted. The point that the "native point of view" not only exists but also matters to the outcome of any endeavor in the world bears repeating - something IK has facilitated. Yet, as Sillitoe argues, IK is not a "socially neutral" concept (1998:231), and any intervention on the topic (by researchers or practitioners) implicates social relations of power. I argue that "indigenous knowledge" is a kind of "structure of common difference" through which local groups are made more comprehensible on the national and international stage. While intelligibility does have its benefits in political struggle, the process also carries with it the possibility of generification. As Ellen notes in a comment on Sillitoe (Sillitoe 1998:238), local people are "increasingly reflecting on their own knowledge, simplifying it and changing it for ideological and legal convenience, and reconstructing it in ways which provide them with an income." Becoming "IK," cultural forms are often transformed into "bite-sized chunks of information that can be slotted into western paradigms, fragmented, decontextualized, a kind of quick fix, if not a panacea" (Ellen and Harris 2000:14). Ellen and Harris (2000:15) also find NGOs, acting as "knowledge-making institutions," as agents of the "reification" of culture. ${ }^{15}$ They caution that IK is "to some extent...in danger of becoming a depersonalised, objectivized concept which, if used as a top-down approach to development, may inevitably lose its agency and efficacy once a new trend is established" (Ellen and Harris 2000:20). ${ }^{16}$

13. However, NGO activists also recognized that NGO-affiliated community leaders played an important role in explaining and spreading tree ordinations from place to place.

14. These criticisms of large-scale protest and formal organization were made around the time of the Assembly of the Poor protests in Bangkok in early 1997.

15. In fact, Brokensha worries that there are signs that "southern" NGOs are starting to see themselves as "guardians of indigenous knowledges" and are resisting attempts by others to investigate that knowledge (Sillitoe 1998:236).

16. It must be noted, however, that conceptual problems with the idealization and reification of IK are recognized by IK advocates within academia (see for example Ellen and Harris 2000, Hunn 1993:15, Healey and Hunn 1993:28, Kalland 2000, Lewis 1993:8, and Sillitoe 1998:227). Clearly, practitioners (including local peoples and their allies) are also aware of the issues at stake, though I hope here to clarify some unintended consequences that may be made clearer by a comparative 
Henry D. Delcore

Several recent cases from elsewhere in Southeast Asia illustrate the simplifying tendencies that often accompany the invocation of IK in struggles over resources (Brosius 1997; Li 2000; see also Zerner 1994). For example, Brosius (1997) describes how, working from information gathered on field visits and from ethnographic accounts (including Brosius' own published work), environmentalists transformed Penan understandings of the landscape into a story about an "indigenous people" connected to "sacred" nature. To make the Penan "narratable and valuable" to outsiders, the activists "reduc[ed] Penan knowledge to the sacred and ineffable," transforming it "into an obscurantist, essentializing discourse which in fact elides the substantive features of that knowledge" (Brosius 1997:60, 64). The very diversity that the activists sought to protect was thus generified: "The essential - and diverse - qualities of indigenous knowledge are lost along the way" (Brosius 1997:65-66). I will return to this line of analysis after a description and preliminary analysis of tree ordinations in Nan in 1996-1997.

\section{Tree Ordinations, 1996-1997}

I focus here on a round of tree ordinations conducted in 1996 and 1997, under the overall aegis of Phra Khru Phithak and HMN, but with important organizational support from NGO activists in Nan and their affiliated village leaders. Like the first two tree ordinations in Nan in 1990-1991, those in 1996-1997 were explicitly aimed not only at conservation, but also the formation of community forests in the ordained areas. Community forests are typically designated for a range of uses by the local community, including hunting, gathering, and collecting firewood (though the rules vary from place to place). Leading up to each ritual, ordaining communities would either revise and strengthen, or create outright, village-level community forest committees and rules. Community forests in Thailand have no legal standing, and attempts to pass a Community Forest Bill through Parliament have repeatedly foundered (see Brenner et al. 1999; Pinkaew 2001). However, the existence of community forests in Nan, particularly when associated with tree ordinations, has resulted in the acquiescence of local officials to limited forms of local management in national forest reserve areas. Yet the existence of community forests runs counter to principles of Thai administration, whereby all management of natural resources is centralized in the bureaucracy, with its apex in Bangkok. Community forest establishment in effect does an "end run" around this centralized system, and represents a de facto (if legally precarious) victory for grassroots environmentalists. ${ }^{17}$

The tree ordinations of 1996-97 were different from previous ones in an important way. The 50th anniversary of the reign of King Phumiphol Adulydej (King Rama IX) was celebrated in 1996. State and private organizations marked the Golden Jubilee with a variety of public celebrations and fundraising drives for the king's various charities and development projects, and the Royal Forestry Department launched a major reforestation campaign in the King's name. ${ }^{18}$ To join in the celebration, POs and NGOs in northern Thailand spearheaded the foundation of the "Program for the Community Forest Ordination of 50 Million Trees in Honor of the King's Golden Jubilee" (Khrongkaan Buat Paa Chumchon 50 Laan Ton Phua Chalerm Phrakiat; PCFO). The twelve tree ordinations performed in 1996-97 in Nan were part of this effort, and therefore had the extra aura of King Rama IX behind them.

Rama IX, a constitutional monarch, is an extremely popular figure in Thailand. The common perception among most Thais is that he is selfless, wise, and personally engaged in guiding national development. The nightly news on state-run television frequently shows the King and

perspective.

17. The efficacy of tree ordinations and community forests in actually conserving forest has not been the subject of systematic study. Anecdotal evidence from my own fieldwork suggests that restrictions on felling trees in ordained forests have been largely respected by both villagers pursuing non-commercial forest activities and by illegal loggers. Sponsel et al. (1998) argue that ordained forests enter into a broader category sacred spaces (such as temples grounds and their surroundings) with potential national significance for forest conservation.

18. Golden Jubilee Network (1999) portrays well the kind of celebration accorded the jubilee in Thailand; it is also a good example of the private and state-sponsored representations of the monarchy that both reflect and reinforce King Rama IX's popularity in Thailand (see below). 
Symbolic Politics or Generification?

other members of the royal family braving sun, rain and mud to visit remote rural areas, where they offer advice and assistance to the poor. All of this fosters an image of selfless devotion to the good of the country. ${ }^{19}$ Aside from any purported personal qualities, Rama IX also fulfills a central role in the construction of Thai nationalism. Since the early 1900s, the slogan "Nation, Religion, and King" has been at the heart of Thai nationalism (see Keyes 1987; C. Reynolds 1993; Vella 1978; Wyatt 1984). This symbolic trilogy - which invokes the unity of the Thai nation, Buddhism as the national religion, and the monarchy - has become deeply rooted in Thai political culture. All Thais who aspire to political goals must wrestle with how to position themselves vis a vis these three key symbols of Thai national identity.

The idea to ordain community forest areas for the King's Golden Jubilee in 1996 originated with Joni Odashao. Joni is a nationally recognized leader of the Karen minority group and founder of the Northern Thai Farmer's Network (Khruakhaay Klum Kaseettakon Phaak Nua), a PO with membership concentrated in the upland minority communities of the north. ${ }^{20}$ In October, 1995, Joni addressed a major meeting of northern Thai NGO activists and farmer leaders: "The King has reigned for fifty years, and there are people who are giving money and goods to the King, which made me think, 'What can we give the King ?' I thought, 'We live in the forests and mountains, we should give the King forest" (PCFO 1996:90). ${ }^{21} \mathrm{He}$ then outlined a plan to ordain a large number of community forests "for the King" during the course of 1996. At first, some NGO activists were opposed to Joni's plan on the grounds that it risked aligning northern POs and NGOs too closely with the state, which they viewed as the source of their resource management problems. But over time, Joni's plan gained support. It became apparent that the tree ordination plan would facilitate alliance building with powerful interests in the government and the broader public sphere, and deliver the powerful symbolism of the monarchy to the grassroots environmentalist cause. One national Thai NGO leader argued that the plan provided a chance to take local tree ordination efforts like those in Nan to the national stage. He noted that with Buddhism and the King both in the picture, no one would dare oppose the plan.

NGO leaders eventually succeeded in organizing the PCFO as a nationwide effort, with a governing committee composed of NGO activists, farmer leaders (including Joni), and state officials, including the director of the state Department of Environmental Quality Promotion (DEQP). At first, the program, through the DEQP, sought to receive ordination cloths, which are tied around the largest tree in the ordained forest, directly from Princess Maha Chakri Sirindhorn. The Princess, popularly known as Phrathep, is King Rama IX's daughter, and within an informal "division of labor" among the King's children, she is seen as the "official patron of cultural heritage" (Hewison 1997:62). The receipt of the cloth directly from the hands of a royal would signal a direct endorsement of the ordinations (and community forestry) by the royal family. The Palace Office, however, turned down the request. One participant in the negotiations reported that the Office, seeing itself as a protector of royal interests, felt that the tree ordinations were "borderline" as a valid activity for royal participation. Instead, the Palace endorsed the program's use of the kanchanaphisek, the seal of the Chakri Dynasty, on the cloths, although the exact locations and uses of such cloths would have to be reported back to the Palace Office. ${ }^{22}$

19. See Hewison (1997) for critical comments on this "standard total view" of the Thai monarchy. Other recent critical analyses of the monarchy include Copeland (1993), Streckfuss (1995), and Thongchai (2002).

20. The Karen, a Tibeto-Burman speaking group that numbers about 300,000 in northern and western Thailand, are widely seen by Thai environmentalists as the most "conservationist" of the country's upland minority groups. See Hayami (1997), Pinkaew (2001), Prasert (1997), Santita (1997), and Uraiwan (1997) for relevant analyses.

21. To mark the Jubilee, wealthy Thais made donations to the various charities and development projects endorsed by the King. This version of Joni's quote is taken from an official publication about the PCFO (PCFO 1996). Observers present at the meeting gave substantially similar accounts of the address. In one version, Joni noted that while other people have money and goods to give the King, "the Karen are poor people" and have only the forest to give.

22. I noticed some confusion among low-level organizers in Nan about the status of the ordination cloths. Several times I heard the cloths referred to as "phaa phraratchathan," denoting cloth received directly from the royal family. When I used this term in conversation with a high- 
Henry D. Delcore

As one of the earliest sites of formal ritualized tree ordinations in Thailand, Nan was expected to play some role in the nationwide effort. However, there was some concern among Phra Khru Phithak and his closest NGO allies that the scope of the effort was too broad. He told me that tree ordinations are meant to "plant consciousness" (pluuk cit samnuk) among villagers about the importance of the forest. But he also felt that any community choosing to hold an ordination should undergo a careful process of education, preparation, and consensus-building before the ritual was carried out (consistent with observations in Darlington 1997:18). He wanted to ensure that ordained areas were cared for properly after the excitement of the ordination had passed; he worried that if ill-prepared communities joined in only to later neglect their community forests, then the sacredness of the ritual would be diminished.

Most of Nan's NGO activists agreed with Phra Khru's cautious approach, with one main exception. Early in the PCFO effort, Somjit, the leader of an NGO in Nan, took on the responsibility of coordinating HMN's participation with the PCFO. Somjit was known to his colleagues as someone who favored the construction of widespread networks of farmers in a large number of villages over the less far flung but more in depth work of his colleagues. Characteristically, Somjit saw the ordinations as an opportunity to draw a large number of villages into the HMN network (and toward his own NGO activities), and in some cases as a start to local conservation efforts. In fact, when I asked him where it was appropriate to hold a tree ordination, he told me that it could be done "anywhere there is a forest." Thus, at regional PCFO meetings in Chiang Mai, he committed HMN to an ambitious schedule of tree ordinations all over the province, a move that further strained an already troubled relationship between him and some of his colleagues in Nan. Once the plan was set in motion, however, disagreements among the NGO activists, farmer leaders, and monks in HMN were not revealed publicly. Outside the inner circle of HMN, the tree ordinations for the King's Jubilee were presented as an initiative with the unqualified support of HMN and Phra Khru Phithak (who presided over nearly all of them).

I stepped into this situation in October, 1996. Within a few days of arriving in Nan to conduct research on NGO development efforts, people were excitedly telling me about the upcoming round of tree ordinations that was set to start in November. Knowing almost no one in Nan, I took the opportunity of tree ordinations to get acquainted with the NGOs and their staffs and visit some of the villages where they were active. Between November, 1996, and February, 1997, twelve tree ordinations were held in Nan, of which I attended nine. ${ }^{23}$ Below, I describe and analyze an

level organizer based in Chiang Mai, he made a point of correcting me, saying that they had merely received permission to use the kanchanaphisek seal on the cloth. Some high-level organizers like himself were acutely aware of the distinction: he noted to me that it was important to get the status of the cloth right, because involvement with royal symbols carried the risk that they might be perceived as abusing the King's good name. He cited the October 6, 1976, massacre in Bangkok as an example of the way misunderstandings involving the monarchy could provide a pretext for suppressing popular action. In that case, one justification for paramilitary and militarypolice action against student demonstrators at Thammasat University was the trumped-up charge that they had hung the Crown Prince of Thailand in effigy (see Morell and Chai-anan 1981; Thongchai 2002). In fact, the struggle to gain royal involvement in the program was wider than the question of the status of the cloth. PCFO organizers actually wanted the Princess herself to attend the inaugural ordination in Chiang Mai in February, 1996, but this request was also denied. However, they scored a major victory at the celebration of Earth Day in Bangkok in January, 1997. One area of the Earth Day exhibition ground was set aside for a tree ordination display. On the day of the Princess' tour of the area, she was slated to spend three minutes viewing the exhibit, but the Palace informed the organizers that she would not tie a cloth around the exhibit's tree, as had been hoped. However, when the Princess actually arrived, she stepped forward and tied the cloth to the tree! That cloth was taken to Chiang Mai and used at the final ordination, of the 50th million tree, in February, 1997. The final ordination was attended by a member of the Privy Council (composed of the King's close advisors) and his presence was taken by some participants as a de facto royal endorsement of the PCFO.

23. In fact, of the tree ordinations held in Nan during that time, only two were "officially" part of the PCFO, which meant that they were registered with the national program and received a small amount of funding to defray expenses incurred by the ordaining communities. The other 
Symbolic Politics or Generification?

ordination that was held in Lay Mun, a rural sub-district located in Sanamchay District, about forty kilometers from the provincial capital.

\section{Tree Ordination in Lay Mun Sub-District}

The tree ordination in Lay Mun Sub-District took place on December 5, 1996 (King Rama IX's 69th birthday), and included participation from all ten villages in the sub-district. The event was spearheaded by Chaiwat, a native of the area and one of the senior NGO activists in Nan. Chaiwat attended the first two tree ordinations held by Phra Khru Phithak. Like the tree ordination of 1991, this one involved representatives from several villages. After the ritual, the representatives would go home with a set of ordination cloths (see below) to tie around trees in their own community forests. Also following precedent, the overall event included the Buddhist ordination ritual and a variety of other animist and Brahmanic rituals. In fact, in this respect, the tree ordination in Lay Mun was the most ambitious that I witnessed: in addition to the ordination itself, it also included the cheedii say (sand stupa), thao thang sii (The Lords of the Four Directions), and suu khwan rituals (see below).

The ordination was held in a forest clearing on the outskirts of one of Lay Mun's villages. I arrived in the area around 9am and found that the Lay Mun villagers were arriving in groups, taking their places under trees marked by signs with each village's name and the size of the area they were ordaining. Eventually, the villagers would be gathered in their places in knots of five to fifteen, facing the front of the clearing. Some of the undergrowth had been cleared to make more open space, leaving a smattering of saplings and a few larger trees, though none over six inches in diameter. Some bamboo had been cleared, and razor sharp bamboo stumps stuck treacherously from the ground to about knee height. Sunlight filtered in patches through the treetops.

Strung over the path leading into the clearing was a twenty foot long banner that appeared prominently at all the tree ordinations I attended. It proclaimed the words of King Rama IX, spoken in his birthday address to the nation in 1994 (my translation):

In a thriving (charoen) forest, you don't have to plant a single tree; they grow on their own. At Mount Cha-ngum, Ratburi Province, in an area right near the mountain, there is forest that was already destroyed, which we call degraded forest, because there were no trees. They started a project there seven years ago and I visited there two years ago after they had set aside the forest for five years. They didn't do anything at all there. A thriving forest had grown up perfectly without having to plant a single tree. Planting forests, it is important to let them grow back on their own. Don't interfere with the trees. Don't bother the trees except to protect them a little. Just don't bother them. You don't have to do much of anything.

I take the use of this passage as an attempt to convey a sense of royal support for community forestry, which calls for reforestation through the protection of existing forests, as opposed to planting tree plantations for later felling.

The focus of the ritual space was the altar at the front of the clearing, a tiered structure of carved wood tables four feet wide and five feet tall, the lower levels occupied by candles, flowers and incense, the top level by a foot-tall Buddha image. To the right of the altar stood an easel with a photo portrait of the King, set about level with the Buddha image. To the left of the altar was a folding table with the microphone for the public address system, where speakers stood to address the crowd later in the day. Directly to the right of the altar were chairs for the monks, who had not yet arrived. Eventually, another cluster of chairs formed near the monk section and would be occupied by the local officials and other honored guests in attendance; the villagers sat on mats on the ground. Directly in front of the altar, mats were spread out over an area extending about 25 feet forward, to facilitate the barefoot movements required of anyone who approached the altar. On the mats sat buckets containing yellow cellophane-wrapped sundry goods to be donated to the

events were only nominally part of the program though in Nan they were accorded no less importance 
Henry D. Delcore

monks, with the ordination cloths on a gold-plated tray at the foot of the altar. Each ordination made use of a primary cloth marked by the kanchanaphisek symbol, which was tied to the "mother tree," the largest tree in the area. A large number of smaller, unmarked cloths, all the saffron color of monks' robes, were also tied by participants to trees in the area. A saay sin - a white string used in many Thai rituals to symbolically bind together the khwan - had been tied to the Buddha image on the altar, and ran around the entire clearing area, encompassing the participants. (Khwan is a kind of soul stuff possessed by both animate and inanimate entities. ${ }^{24}$ ) Over the altar, a twenty foot long banner announced the formal title of the forest ordination program: "Program for the Community Forest Ordination of 50 Million Trees in Honor of the King's Golden Jubilee."

About twenty feet to the front of the altar, someone had prepared a cheedii saay (sand stupa). The sand stupa is a Brahman-Buddhist ritual. This arrangement was a three-tiered sand structure, with the base tier three feet by three feet, a few inches high, sides shored up by split banana stalks. The other two tiers, also bound by banana stalks, were a few inches smaller all around, thus forming a rough pyramid. Six-inch tall cones of wet sand, symbolizing stupas (like the entire structure itself) surrounded the edges of the base tier. In the sand at the top were stuck banana and sugar stalks, with paper forms of fish hanging down from their tips. The miniature stupas typically number 99; the larger stupa makes one hundred. A previous sand stupa ritual I observed (not connected to a tree ordination) was interpreted to me by a monk to mean that the relatives of a dead person build one hundred stupas for them as a way to "chay kam," or negate the demerit that the person incurred in their life. The ritual can also be performed for the spirit of a dead person thought to be causing illness among the living. Once the structure is complete, a monk chants briefly over it (see below). After the ordination, I asked a monk associated with local NGOs about the rationale for including the sand stupa in the event. He said that regular sand stupas call on the dead to heal a sick person, but the sand stupa at Lay Mun was meant to call on the thewadaa (deities) to help care for the forest. ${ }^{25}$ More importantly, however, the idea was to draw more thewadaa into the area and therefore make it more sacred in the eyes of the local people. He himself was skeptical about the existence of thewadaa, but recognized that they are a strong force in the eyes of the villagers. Thus, he noted, the use of the sand stupa was a "device" (ubaay) to make the local people more careful in their activities in the ordained area.

Another ritual was being prepared on the edge of the clearing. The "thao thang sii" (The Lords of the Four Directions) is a ritual performed for the local spirits and deities. When I arrived, Uncle Lae, a ritual specialist from a nearby village, and a few other elderly men were finishing their preparations. Four wooden stakes were driven into ground to form a square about four feet wide, with a fifth stake in the middle. In this case, the middle stake was planted into a white ant nest, which rose cone-shaped a few feet from the ground; such nests are thought to mark spiritually potent places. Stuck on top of each stake was a tray made of hollowed banana tree stalk,

24. At other ordinations, the saay sin was wound around the entire forest area to be ordained, though this was impossible for larger areas. Each person is said to have $32 \mathrm{khwan}$, which are arranged in the body in a particular way (though khwan are seen as distinct from the winyaan, ones spiritual essence in the Buddhist sense). A proper arrangement of khwan produces good health, while a disorganization or loss of khwan can result in serious illness. A suu khwan ritual can be performed on people who are ill or have suffered an injury to ensure that the khwan are strong and well-ordered, or in preemptive fashion before a person undertakes a dangerous activity, like a long journey. Rice, water buffaloes, and trees are examples of non-human entities thought to have khwan, and the ritual can be performed for all of these. The ritual is largely Brahmaninspired but also has some Buddhist and indigenous Tai elements (on khwan, see Anuman 1962; Kirsch 1977; Tambiah 1970).

25. Thais distinguish between phii (spirits) and thewadaa (deities). The category "phii" includes troubled spirits of the deceased (ghosts) and ancestor spirits, as well as non-human entities, such as village and city guardian spirits, house spirits, place spirits, and spirits that inhabit various aspects of nature (streams, trees, etc.). "Thewadaa" (a Pali-Sanskrit derived word) are minor deities that inhabit the heavens, but also have some dealing with humans. They are generally seen as divine and morally consistent, while phii are more capricious and can be quite malevolent (on the distinction between phii and thewadaa, see Stanlaw and Bencha 1985; Tambiah 1970; and Textor 1960). 
Symbolic Politics or Generification?

filled with offerings (sticky rice, fruit, and flowers; offerings at other thao thang sii I observed included cigarettes, fish, and sweets). At the foot of the nest was a plate containing similar offerings. In addition, four containers had been strung from surrounding trees so they hung around shoulder height four or five feet out from the main structure, roughly aligned with the four outer stakes. A foot wide and several inches deep, these containers were also made of banana stalks, held together by tiny bamboo pins and lined on the inside with newspaper. They too contained offerings like those on the inner structure. As I watched, Uncle Lae knelt at the foot of the nest and chanted briefly in northern Thai.

The four outer stakes were for the local place and nature spirits, the middle stake for the deities (which are associated with the sky), the plate on the ground for mae thoranii (an earth deity). Uncle Lae explained that the thao thang sii is performed to tell local spirits and the deities what is being done by all the people gathered there, and to promise not to bother them. ${ }^{26}$ Place spirits do not like crowds or loud noises, and failure to inform and appease them might provoke an attack on someone with weak khwan, causing them to faint or become ill. This was a common interpretation of the ritual given to me by other specialists. In contrast, some NGO workers and village leaders claimed that the use of animist rituals was intended to invoke local spirit protection of the area, thus strengthening the sacred prohibition against cutting trees. Phra Khru Phithak was credited locally with coining the phrase "phra dii phii du chuay kan," which translates roughly as "the good Buddha and fierce spirits help each other." In other words, cutting trees in an ordained area might bring not only karmic retribution, but also retaliation from protective spirits. ${ }^{27}$ Thus, when I asked Somjit if he thought that local spirits actually protected ordained areas, he said that he did not personally believe so, but the important point had to do with "psychology": that the villagers believe that the forest is home to spirits and that this aids in promoting conservation. ${ }^{28}$

From 9:00am until about 10:45am, Chaiwat and several other organizers talked continuously

26. In villages with well-developed village guardian spirit cults, villagers performed a similar ritual to the guardian spirit for the same reason prior to their tree ordinations.

27. The incorporation of animist rituals into tree ordinations is not without controversy among Thai ecology monks. Some monks have been reported to object that the animist rituals appeal to peoples' fears of spirits (see Darlington 2003) and obscure the Buddhist emphasis on creating a proper understanding of the value of forest conservation. The use of animist rituals under Phra Khru Phithak's guidance, however, did reveal an astute awareness of the enduring importance of spirit beliefs and their instrumental value in promoting forest conservation.

28. There is evidence that some villagers elsewhere had come to see local spirits as protective of ordained areas, particularly in Phra Khru Phithak's home village. There, stories circulated about several deadly accidents that befell villagers who violated the rules covering the ordained area as a result of retribution from local spirits. However, in the villages where the ordinations of 1996-97 were held, among villagers I only encountered Lung Lae's more restricted explanation for the animist component of the ordination. (It is of course possible that in the future, villagers near the newly ordained areas in Lay Mun will develop their own stories about the role of "fierce spirits" in protecting ordained forests.) Interestingly, the differing views of the purpose of animist rituals within a tree ordination held up in the upland minority Mien village whose ordination I attended. There, a Mien shaman was invited by the NGO organizers to perform a spirit ritual just before the tree ordination itself. A Mien village headman closely allied with the NGOs told me that the shaman was calling the spirits to help protect the forest. I was able to interview the shaman later and although our mutual limitations in spoken Thai were an obstacle, he was able to inform me that the ritual was one commonly conducted to cure sick people, ensure successful harvests, promote the growth of livestock, and inform the spirits whenever major activities were undertaken in the forest. On the latter point, he said that the spirits had to be informed of any large, noisy gathering in the forest in order to avoid their angry retribution in the form of sickness. When I asked specifically if the ritual was meant to invite the spirits to help care for (raksaa) the forest, he said "yes," but followed with the observation the ritual would protect the villagers if they came to the forest to do something in the future. I think it is clear that, in contrast to the headman, he shared with Lung Lae a rather more narrow interpretation of the role of spirits in "protecting" the ordained area. 
Henry D. Delcore

over the PA system about the schedule for the day and about local conservation efforts. ${ }^{29}$ At one point, Chaiwat talked about how each tree has a spirit. He also compared the tree to the human body, noting that both have flesh, blood, and breath (mentioning that both need air to live): "Trees and people are the same." By 10:45am, chairs had been set up in the middle of the clearing and Chaiwat began an educational seminar featuring a panel of local people: a teacher, a former headman, a youth group leader, and Phra Khru's brother, who was headman of a village in Sanamchay District. Chaiwat asked them questions in turn, and each took the microphone and discussed their experiences with conservation. Talk turned repeatedly to the royal family. The teacher talked about the health hazards of chemical residues on food, and mentioned that he had heard that the King had directed Princess Sirindhorn to do research on organic vegetables. Phra Khru's brother talked about how the King himself was a "conservationist" (nak anurak) and nature lover. The villagers scattered around the clearing listened and chatted among themselves. After the seminar, Chaiwat called on everyone to break for lunch. Though some of the villagers had packed their lunch with them, I was forced to leave the area and go back into the nearest village for food. When I returned at $1 \mathrm{pm}$, I found I had missed the performance of the thao thang sii ritual, which had apparently involved the collective chanting of lay ritual specialists from several Lay Mun villages.

Throughout the morning, Chaiwat had repeatedly announced that "foreigners from nine countries" would be visiting the event. In Thailand, foreign interest in any event is welcomed and generally taken as a positive sign that the event is worthwhile, reflecting both Thai aspirations to play an important role on the global stage, and a deep-seated pattern whereby knowledge and influence gained from a distant source carries special power. Although I remember thinking at the time that Chaiwat's prediction could not possibly come true, it did. Shortly after $1 \mathrm{pm}$, a group of about twenty foresters from around the world (including China, Vietnam, Malaysia, Laos, Nepal, and Kenya) arrived at the clearing. They were students at the Regional Community Forestry Training Center (RECOFTC), an FAO-funded program based at Kasetsart University in Bangkok, which educates state foresters about community forestry. Groups of foresters attend RECOFTC's four month training sessions, which include a trip upcountry to see community forestry in action. The group's arrival spurred a ripple of excited murmuring around the clearing. One of the Thai professors accompanying the group spoke over the PA and explained that they came to see the tree ordination ritual because they were interested to see if the method might be used in their own countries, adapted of course to their own religions. The students then sat on some mats in the middle of the clearing and ate lunch.

Phra Khru arrived at around 1:30pm, leading about ten novices and younger monks to sit near the altar. This group did not chant during the ritual. While Phra Khru attended almost all of the tree ordinations I witnessed, he did not participate in the chants at any of them. Instead, the chants were led by the senior monk present. At Lay Mun, the senior monk was the chief sub-district monk. He was accompanied by the senior monks from the other two sub-districts of Sanamchay, and six other monks from around the district. They took up chairs to the right of the altar, facing Phra Khru's group and the rest of the clearing.

One of Chaiwat's helpers took the microphone to explain that the Sanamchay District Head the intended guest of honor - was detained by official business and unable to attend. He went on to

29. Among the organizers, Kamnan (Subdistrict Head) Put played a prominent role. Kamnan are the highest elected officials in the local government structure; the next highest official, the District Head, is appointed by the Ministry of the Interior. In Sanamchay District, community forests, tree ordinations, and HMN activities in general enjoyed the support of all three kamnans. Their support dated back to Phra Khru's district-wide tree ordination in 1991. A Sanamchay native, Phra Khru had worked carefully to include his monk superiors and local state and informal leaders in the plan for the event (see Darlington 1998). The three Sanamchay kamnans eventually formed a community forest organization to coordinate their efforts (Chomrom Anurak Paa Chumchon Amphee Sanamchay, the Sanamchay District Community Forest Conservation Association). Kamnan Khit, the kamnan of Lay Mun, had attended the ordinations in 1990 and 1991 and was among those interested in bringing the King's ordinations to his subdistrict in 1996. Kamnan Put, though from a neighboring subdistrict, helped direct the ritual because he had spent a lengthy tenure in the monkhood. 
Symbolic Politics or Generification?

list the various leaders from within HMN and the officials from Sanamchay who were in attendance. The head of the district adult education office, as the highest ranking official present, stepped in to become the guest of honor. The District Head's absence was quite a disappointment to Chaiwat and the other organizers, though it was unclear whether his absence was an intended slight or not. (In the past, there had been some tension between the NGOs and the Sanamchay District head, but those differences had supposedly been smoothed over.) Since a major goal of the tree ordinations was building cooperation with various social groups, including state officials, the organizers always invited a senior official to serve as guest of honor. In fact, the first PCFO tree ordination in Nan in November, 1996, was officiated by the provincial governor.

The ordination ritual began at about $2 \mathrm{pm}$, beginning with the lighting of altar candles by the guest of honor. As the Pali chants got underway, the senior monk prepared a bowl of holy water by stirring it with a handful of reeds and dripping candle wax. Meanwhile, Chaiwat and a few helpers planted a bodhi tree (ficus religiosa, the kind of tree under which the Buddha sat when he achieved enlightenment) during the chanting. Consensus among organizers, monks and spectators was that the chants were the most important part of the ritual itself. Thais generally believe that attendance at chanting is a merit-making opportunity, though not all lay people understand Pali. Some chants used at tree ordinations were deliberately chosen by Phra Khru for their relevance. One chant used at several tree ordinations recounts the Buddha's discipline for monks, which includes prohibitions against cutting trees to build shelter or building fires in the forest. The chant used at Lay Mun dealt with the Buddha's teachings to a group of newly ordained monks, which details the way of the Middle Path and emphasizes the importance of moderation in all things. Though the message of the chants was not apparent to some lay villagers, Phra Khru made a point to explain the meaning of the chants in his speech at each ordination (see below).

After about twenty minutes, the chants were done, and the adult education head delivered a brief speech. Then, he and the other local officials in attendance went forward to present the wrapped baskets to the monks. (Though the offerings were prepared by the organizers, the local dignitaries were always given the honor of making merit through this presentation.)

Phra Khru then came forward and delivered a speech. He began by noting that the King was the only living monarch in the world to have reigned fifty years. He then asserted that all Thai people, uplanders and lowlanders, of many different ethnic groups, are united by their common nationality. "We all love the King," he asserted. Echoing Joni's words from 1995, he said that wealthy people have money to give the King for the Golden Jubilee, which he uses to "develop the nation." But "people like us," he said, "country people" (khon baan nok), are in a hard way (lambaak). We have only the gift of the forest to give, he said, but this gift is equal to the millions of baht given by "rich people in Bangkok." ${ }^{30} \mathrm{He}$ went on to describe the upcoming tree ordinations that were planned, and noted the work of the HMN activists. But he pointed out that HMN played merely a "coordinating" role, while the ordaining communities were themselves the true organizers of the rituals. He noted that tree ordinations are not "for fun" (kaan len, or "playing around"), but rather an important expression of peoples' thankfulness to the forests and waterways on which they depend. Phra Khru then briefly recounted the life of Gotama Buddha, emphasizing the connections between the Buddha's teachings and the forest. At one point, Phra Khru touched on the new restrictions relating to the ordained area, saying that the villagers could still collect mushrooms and bamboo shoots form the area to eat, but that no more trees would be felled. Raising his hands, palms together before him, Phra Khru again recognized all the people who worked and sacrificed to make the event happen, and called on the spirits of the forest to come witness what they have done. He then chanted the phaemeethaa, a closing chant for many Thai Buddhist rituals that invokes the karmic connections between all living things.

Like other talks I heard Phra Khru deliver, his address displayed his well known skill at oratory. He spoke in a straightforward but unpatronizing manner, and walked a fine line between criticism of the prerogatives of the powerful and recognition of the existence of righteous power. Careful not to slight the giving of money to the King, he nonetheless asserted the value that lay in

30. Joni's rationale for the tree ordinations, as stated here, was repeated many times by people in Nan, in both interviews with me and in public statements. The night before the Lay Mun tree ordination, a temple celebration was held at the sub-district seat, and one of the NGO activists involved invoked Joni's words in a speech about the meaning of tree ordinations. 
the nation's forests. By extension, he argued for the patriotic and religious value of community forest conservation. Phra Khru also made explicit for the audience his view of the doctrinal underpinnings of eco-Buddhism.

After his address, Phra Khru called on the audience to join in singing the King's anthem, which is distinct from the Thai national anthem. Everyone rose and stood at attention. At other tree ordinations, a tape of the anthem was played and the audience sang along. At Lay Mun, there was no tape, but a local sub-district head led the singing in a strong voice. Absent the music, this rendition of the song struck me as particularly powerful, as the audience sang from memory and in reverent tones the words of the song, which extol the virtues of the royal family.

The final series of events came in quick succession. After a brief chant, the senior monk circulated among the crowd, blessing everyone with holy water - another key merit-making event. The adult education head was handed the stack of unmarked ordination cloths, which he distributed to representatives from each of the ten villages. The villagers went around the clearing and surrounding forest to tie some cloths to the largest trees, reserving others for use in their own villages. At the same time, Phra Khru and the guest of honor took the cloth marked with the kanchanaphisek symbol to tie around the "mother tree." (At Lay Mun, the mother tree was only about six inches in diameter, though mother trees at other ordinations were five or more feet in diameter.)

Shortly thereafter, each village delegation began performing a suu khwan ritual to strengthen the khwan of its designated tree (an idea introduced by Chaiwat). ${ }^{31}$ At the same time, the senior monk took a chair in front of the sand stupa and chanted. By about $4 \mathrm{pm}$ the villagers finished their suu khwan rituals and quickly packed up their mats and other belongings; some had been sitting in the clearing for about seven hours. The foreign foresters gathered for a group photo while Chaiwat and his helpers began packing in the chairs, tables, mats, and other items. Two local NGO activists agreed to lead the foreign foresters to Phra Khru's home village to see the site of Nan's first tree ordination.

\section{“Just a Mechanism"}

Why were the tree ordinations of 1996-97 performed ? First, as with other tree ordinations, the organizers sought to strengthen community forest institutions and to discourage anyone interested in cutting trees in the ordained area, including illegal logging interests and members of the ordaining communities themselves. This is the most explicit and instrumental use of the ritual for forest conservation. That religious ritual had become something highly instrumental in relation to these goals is obvious from the organizers' commentaries on its various components; the sand stupa was seen as a "device," and the thao thang sii as a psychological tool, to encourage attention to community forest rules (see above). Likewise, in a conversation with an ecology monk who was thinking of organizing an ordination in the village where he was the temple abbot, I asked about the rationale for using animist rituals in tree ordinations. He replied, "It's a device" (pen kusalobaay). "The villagers believe in this, so we take it and use it. But in reality, there aren't all the spirits the villagers believe in. But some villagers' knowledge of Buddhism, of the Buddha, Dharma, Sangha, may not be very deep. But they know about spirits, and believe in them." ${ }^{32}$ A

31. I observed one of the village delegations do their suu khwan ritual. The main item used was a bay sii suu khwan, a structure made of one or more gold-plated trays containing woven banana leaf forms, flowers, and offerings of sticky rice, oranges, and bananas. As the suu khwan ritual specialist chanted, another man tied a saay sin from the bay sii to the tree. During the chanting, the specialist's assistant took the offerings from the bay sii and laid them at the foot of the tree. Once the chants were done, the villagers disassembled the entire bay sii and laid everything but the trays at the base of the tree.

32. Ironically, this same monk reported to me that the state officials in his area were actually pressuring him to go ahead with an ordination because while he would be the main organizer, the officials would claim credit for the event. But he was committed to waiting "until the villagers are ready," meaning that the groundwork of consensus and understanding about community forest conservation had yet to be laid. This indicates that at least in some areas, the tree ordinations for the King had become part of the repertoire of actions aimed at building power and status within 
Symbolic Politics or Generification?

Western volunteer working with one of the NGOs in Nan was perhaps most explicit. On my second day in Nan, he said to me, "Tree ordinations [are] just a mechanism" to get villagers interested in conservation. ${ }^{33}$

Some local leaders, who helped build support for ordinations in particular communities, shared similar attitudes. The headman of a village that had recently begun hosting an NGO project was approached by the NGO worker assigned there about having an ordination. He told me that he was immediately drawn to the idea because the ritual, having sacred power (sak sit), would make the villagers afraid (kreng) to cut the forest. The ritual would make cutting trees the equivalent of killing a monk. "It's a trick" (kon), he concluded. Asked if the "tricky" aspect of the ritual, should it become apparent to the villagers, would make the ritual less effective, he asserted that it would not, because no matter what the villagers thought about it, the ritual was still spiritually potent. In other words, even if the ritual was done for purely instrumental reasons, it was nonetheless a sacred act and would create sacred sanctions for breaking whatever local strictures were set up in the ordained area. I believe that it is reasonable to point out that the consensus of the villagers about the relative merits of conservation and community forestry could be seen as beside the point; they were bound to "follow the rules" once the ordination was over. Thus, while Phra Khru and others certainly sought to build understanding about the spiritual and practical benefits of forest conservation and community forestry, the rituals themselves involved a fairly straightforward use of fear to extract compliance from local people, some of whom were in fact wary of yet another restriction placed on their use of local forests. ${ }^{34}$

The ordination organizers also hoped to use the rituals to inform local state officials about their efforts, and perhaps extract their support. Although they represent an innovation on Buddhist ritual, tree ordinations are nonetheless religious events. As such, there is pressure on most Thais to either reserve judgment on them, or actively participate. With the tree ordinations in honor of the king, the force of the rituals was increased. The organizers explicitly exploited the symbolic force of the monarchy by inviting local dignitaries to serve as guests of honor and keynote speakers at ordinations, in effect compelling their involvement in grassroots environmentalism as a civic duty to nation, religion, and king. Once on site, the officials are confronted by banners with the King's words and his portrait next to the altar, signaling that this is a patriotic and pro-royal event. Another important audience was the urban middle class, including both those sympathetic to grassroots environmentalism and those who were skeptical about rural peoples' conservationist credentials. Two of the larger ordinations I observed (though not the one at Lay Mun) had TV and print media coverage, which was sometimes provided by sympathetic journalists at the request of the NGO activists themselves. Several activists argued that the rural-urban and village-state alliances that might flow from tree ordinations were among the most valued possible outcomes of the entire effort.

Thus, the NGO organizers were well positioned to explain themselves to a larger audience. But to be more precise, they sought to explain not themselves per se, but rural people and their relationship to the forest. Faced with a political challenge (the legitimation of community forestry and local control of resources), they examined - though certainly not for the first time - the purported conservationist values and practices of rural people, and put them on display in the form of a Buddhist ritual comprehensible to those with little experience in the countryside. But the ordination, with all its attendant sub-rituals, had to first be objectified, as an expression of rural peoples' love and respect for nature, and generified as an example of "local wisdom." Once framed in terms of the structure of common difference known as "local wisdom" in Thailand, or IK on the global environmentalist stage, the local people were comprehensible to both their

the bureaucracy, because local officials could point to the event in their area as evidence of their devotion to the King.

33. But, he pointed out, they had to be followed up with the formation of a community forest committee, and village meetings aimed at building local consensus about conservation. In fact, he criticized Somjit for his failure to build such follow up measures into his plans.

34. Sponsel et al., in a sympathetic treatment of the contributions of sacred spaces like ordained forests to conservation, recognize this element of fear: "Religious sanctions may be more effective than government regulations, because individuals fear misfortune, illness, or death to themselves or relatives as a result of violating sacred places" (1998:161). 
Henry D. Delcore

opponents and potential allies as good, nature-loving (and patriotic) folk. In the process, their distinct religious beliefs and practices were presented less as unique statements of truth about the world, and more as generic, situationally focused signs of the desire and capacity for forest conservation. Certain sub-rituals that were part of the event were explicitly reinterpreted by the activists as having conservationist goals. For example, the organizers tended to see the thao thang sii ritual as a way of ensuring local spirits' protection of the forest, while the villagers practiced them as merely necessary accompaniments to the entire event, to inform the local spirits of their activities and prevent mishaps.

The presence of the foreign foresters underscored the generifying implications of the rituals. It was suggested that the foresters might carry some version of the tree ordination method back to their home countries, adapting it to their own local cultures. But is it so certain that the social and religious context back home can accommodate to the use of ritual for conservation ? It was merely assumed that people in Kenya or China also "love and respect nature," and that their own religious rituals could be rearranged and reframed in the service of local forest management. The content of the beliefs in question - their own unique statements of truth about the world - mattered little.

\section{"We All Love the King"}

Why did particular villages participate ? All of the ordinations I attended were in villages where local NGOs were active, and where consciousness about environmental issues was relatively higher than elsewhere. Thus, there was in fact real support among at least a subset of villagers in those communities for establishing or strengthening community forests, and legitimizing local control of resources in general. In Lay Mun, for example, Chaiwat (a native of the sub-district) had been active in development work in the area for almost twenty years, HMN was well-known locally, and Phra Khru was both well-known and highly respected. The subdistrict had taken part in Phra Khru's second tree ordination, the district-wide event of 1991, which had led to the foundation of several local community forests. Thus, the idea of tree ordinations and community forestry were relatively well known in the area. However, it is also true - in Lay Mun and virtually everywhere else - that the 1996-97 tree ordinations were spread to specific communities primarily through the work of the NGO activists, who suggested or at least opened up the possibility of holding an ordination in their project villages. In only three of the nine rituals I attended, significant impetus to conduct the ritual came from village leaders working with NGOs, as opposed to the other way around. ${ }^{35}$ Isager and Ivarsson provide independent confirmation of the "significant roles" played by NGO activists and ecology monks in organizing tree ordinations in northern Thailand (2002:395); they describe an ordination held in Chiang Mai Province in 1996 as part of the PCFO effort, and another held in Nan in 2001.

I know of no case in which a community declined to participate outright, although there were several that asked to defer participation until a later time (i.e. after the Jubilee year) because they were "not ready," which usually meant that there was not enough local consensus about community forestry and the restrictions to be placed on the ordained areas. Where local leaders decided to take on an ordination, there was a period of consensus building within the community. In some cases, the consensus building process was pressed into a mere few months before the event, and was not always an easy process. The NGO organizers admitted to me that many villagers in the communities did not understand the point of the ritual, because the idea of ordaining trees (as opposed to monks) did not immediately make sense to everyone. In several cases, Phra Khru Phithak himself agreed to meet with the villagers and explain the history of tree ordinations and the general relationship between Buddhism and conservation. Once the concept of "tree ordinations" and their rationale was clear, people in several villages expressed concern that restrictions on ordained areas would be too tight and would thus limit their ability to pursue their activities in the forest. This was usually addressed by assuring them that each village had the right to specify the size of the ordained area and the exact rules that would apply there. The only common rule was a prohibition of cutting trees, but other restrictions (on hunting and gathering,

35. All three case, including Lay Mun, were communities where NGO activism was quite well established and where a cadre of NGO-affiliated local leaders was attuned to the potential usefulness of the ritual in local conservation efforts. 
for example) were a local decision.

Through all of this, PCFO organizers (in both Nan and Chiang Mai) admitted that the fact the ordinations were devoted to the King was a significant factor in catalyzing local support for the ritual in each community, including Lay Mun. In two cases of ordinations in Nan, the lead NGO organizers told me that the fact that the ordinations were for the King was the key factor in promoting village consensus to hold an ordination. In another case, the village headman told me that when his NGO connections brought up the ordinations, he felt that the village had a strong community forest organization already, but decided to hold an ordination anyway because "there's only one king of Thailand, and no other king [in the world] has ruled for fifty years before." 36 When he met with the rest of the villagers, he cited Joni's rationale for donating forest to the King, and the idea quickly gained support. ${ }^{37}$ None of this is meant to imply that villagers involved in the ordinations were uninterested in forest conservation. However, I argue that in this particular round of tree ordinations, the King's Jubilee in effect overshadowed the forest itself as both a rationale for having an ordination, and in the actual way the rituals were conducted.

Thus, while the rituals have heightened awareness of grassroots environmentalism among state officials and others, they could also be read as rituals of disempowerment for rural people. Each ritual was a complex performance in which multiple dimensions of inequality in Thai society were enacted and validated. For example, the organization of the ritual space closely reproduced real inequalities of wealth, power, and prestige in Thai society. In the ritual space, the guest of honor (always a man) and other powerful guests (almost all of them male state officials) sat in front on chairs, while villagers sat on mats on the ground behind them. Among the villagers, men usually sat to the front of women and children, although sometimes elderly men and women both sat in front. This spatial arrangement reflected the reality in which state officials wield real power over important decisions affecting villagers, and symbolic power as state officials or "khaaratchakaan" - "servants of the King." Male dominance at the higher levels of the state bureaucracy, and in at least the public sphere of village life, was reflected by the position of men ahead of and above women. Of course, monks sat to the front of everyone, either on chairs or on a raised platform next to the altar, reflecting the respect accorded monks in general and the powerful place of the Sangha as an institution. The altar itself was topped by the Buddha image, and a portrait of the King was always located right next to the altar and on a level roughly equal to the Buddha. (The Thai flag was typically positioned near the altar, as well.) The spatial arrangement thus reflected the real and symbolic hierarchy of the Thai society, stretching from the Buddha and King at top, down to monks, state officials and other powerful men, and finally villagers. At each point, men tended to be before and above women. ${ }^{38}$

36. Actually, it is more accurate to say that at that time King Rama IX was the longest reigning monarch alive. On the other hand, I did meet one headman in another ordaining village who cited the conservation value of the ritual, as demonstrated by Phra Khru's home village, as the main reason he accepted his NGO friends' invitation to participate.

37. I also wonder, however, how free community leaders and villagers were to decline to participate. While the NGO activists in Nan were not the type of people who would punish a community that declined participation, the very fact that the royal Jubilee was part of the rationale for ordinations would make a declination a potentially damaging decision. For example, a leader's local political opponents might exploit a supposed lack of enthusiasm for the Jubilee on the part person declining to hold an ordination. This is however speculation, since I was not close enough to the political machinations in the ordaining villages to know if such incentives were operating. However, given the political sensitivity attached to anything royal, such considerations seem warranted.

38. I attended two ordinations in non-Tai communities: Mien and Hmong. At the Hmong event, yet another aspect of hierarchy in Thai society - lowland dominance of upland peoples - was clearly enacted, as well. The guest of honor that day was a provincial vice governor. In his speech, he weakly commended the Hmong villagers for undertaking the ritual, but strongly admonished them for being the most environmentally destructive group in the north, noting that wherever one sees a Hmong village there is widespread and severe deforestation. In this way, the vice governor was given the chance to assert a common and somewhat flawed interpretation of the roots of deforestation in northern Thailand, and to enact the real and symbolic dominance of the 
Henry D. Delcore

In the action of the ritual itself, the more powerful attendees were dominant. The monks, of course, conducted the chants and other functions common to Buddhist rituals, sometimes assisted by a male lay ritual leader. The guest of honor lit the candles at the start of the ritual, and delivered a speech. Other speech makers included Phra Khru Phithak and sometimes an NGO activist (always a male). The guest of honor usually helped plant the symbolic new tree, and, with Phra Khru Phithak, wrapped the mother tree in its cloth. The powerful men in attendance were the ones who made the merit-making donations to the monks. At Lay Mun, however, there was more diverse participation from villagers than at all other tree ordinations I attended, due in part to the efforts of Chaiwat, the lead organizer. For example, a teenage girl (the youth leader) spoke during the pre-ritual seminar. The one form of wider participation that was practiced at all events was the post-ritual tying of ordination cloths; anyone present was able get one of the smaller cloths to tie around trees in the ritual area, and in fact all categories of people - rich, poor, old, young, male, female - took that opportunity.

The rituals did have a unifying function. Buddhism itself has a powerful egalitarian strain because all beings are subject to the law of karma. After the ritual, no one would be exempt from the karmic consequences or spirit retribution that would come from violating the restrictions on forest use. More specifically, the use of white string to encircle the ritual space symbolically united all present as bearers of khwan. But the most prevalent form of unity pressed by the rituals was the political and social unity of the Thai people in their common devotion to the King. As stressed by the banners and speeches, the ordained forest was a gift to the King on his anniversary on the throne, because (as Phra Khru himself asserted) "we all love the King." Importantly, during the Buddhist portion of the ritual itself, the only opportunity for active mass participation was when everyone stood to sing the royal anthem. Thus, the kind of unity stressed by the ritual was unity in hierarchy. In effect, the ritual graphically displayed and affirmed the legitimacy of political and social hierarchy of Thai society, with the King at its pinnacle.

\section{Conclusion}

Jackson (1997) argues that while Thai state interest in the regulation of religiosity decreased during the 1990s, Buddhism is still an important touchstone for legitimation of various and often conflicting political projects. A reason for this continued centrality of Buddhism to politics may lie in Gray's application of Bourdieu's argument that "competition for control over the symbolic instruments of power is most intense in situations of crisis" (Gray 1991:49). Capitalist economies are marked by periodic crises, and class societies "are characterized by an unceasing struggle for the power to impose a legitimate mode of thought and expression on their members" (Gray 1991:49-50). As people in Nan and other predominantly rural areas attempt to adapt to repeated social, economic, and environmental upheavals, Buddhism will likely remain a "symbolic instrument of power" that various actors attempt to grasp and employ to press their particular visions of the good society.

The arguments of Jackson and Gray can be extended to the Thai religious system as a whole, with its Buddhist, animist, and Brahmanic elements. Tree ordinations are just one example of a broader pattern whereby the self-conscious deployment of sacred ritual for instrumental ends has become increasingly common in modern Thailand. As Tanabe and Keyes (2002:25) note with Thailand in mind, "Modernity changes the status of traditions and makes them objects that can be talked about and strategically manipulated" (see also Morris 2002). Of course, the use of sacred ritual to generate state legitimacy and loyalty is not new to the Thai realm (see F. Reynolds 1977; Tambiah 1976; see also Bowie 1997 for a parallel in secular ritual). However, since the late-1980s, the use of ritual for political ends has been "democratized" and has become more self-conscious than ever before. Not surprisingly, many recent cases of ritual deployment have been in conflicts over resources, with NGO activists as important actors. One case with striking parallels to the tree ordination phenomenon occurred at the Pak Mun Dam (northeastern Thailand) protests in 2000, where the Assembly of the Poor and its NGO advisors deployed a ritual for the Goddess of the River to draw attention to the anti-dam struggle (Rungrawee 2002:25-26). Local villagers believed in the existence of a river goddess, but had no tradition of ritual worship for her. An NGO advisor

lowlander-dominated Thai state over the upland minorities. 
Symbolic Politics or Generification?

saw pictures of Indian Narmada Dam protesters conducting a ritual protest in the water, submerged to their waists. He worked with the Thai protest leaders to develop a similar ritual for the goddess of the Mun River, which was framed as an act of worship and a protest of the fact that the dam would obstruct the walking path of the river goddess. The NGO activist noted that the ritual was aimed at boosting protester morale and attracting media attention, which had been flagging. (For other examples of the deployment of religious rituals in conflicts over resources in Tai-speaking and predominantly Buddhist communities, see Coordinating Committee for Southern NGOs 2002, Montree at al. 1992:154-155, and Tegbaru 1997:165-201. On parallel processes of objectification of ritual among the Karen, see Karnjariya 1997.)

While ritual manipulation in the service of grassroots causes could be taken as a hopeful sign, I stress here the ambivalent implications. True, the actual areas that are being conserved are a significant potential source of environmental well-being in the face of decades of reckless forest exploitation and expropriation of resources by state and private interests. Tree ordinations and related practices do foster among the urban middle class and state officials more awareness of grassroots environmentalist arguments, and the use of Buddhist and royalist idioms further legitimizes practices like community forestry. The establishment of community forests via tree ordinations could be seen as a method of establishing a category of customary rights, which have been notably absent from Thailand (Peluso and Vandergeest 2001:778). In fact, Isager and Ivarsson (2002) see tree ordinations as a method of local resistance to the progressive extension of Thai state control over resources through the process of "territorialization," which includes such state moves as zoning land as forest reserves or protected areas (Vandergeest and Peluso 1995). Yet, in spite of these challenges to state claims of control over resources, the tree ordination rituals for the King in 1996-1997 were also potent displays of hierarchy and inequality in Thai society. As discussed above, the rituals symbolically bolster the legitimacy of the state, its functionaries, and their symbolic head, the King. Any political benefits the rituals deliver to the cause of grassroots environmentalism will have to be weighed against this contradictory and somewhat unintended outcome.

Tree ordination rituals also enact the inequalities that exist within the grassroots environmentalist movement. Although tree ordinations originated with monks and continued in Nan under Phra Khru Phithak's stewardship, the main agents of their elaboration and spread were middle class NGO activists. The NGO organizers objectified the ritual (and its attendant symbols) as a discrete cultural form open to use for political ends. Toward these ends, the organizers sought to frame what is in fact a multivocal ritual event with complex symbolic elements as a fairly straightforward statement of local commitment to and proficiency at forest conservation. The ordinations and the various Thai religious symbols and rituals involved in them were thus generified as general examples of local wisdom in a way that made them comprehensible to nonlocal actors (state officials, the media, and the urban middle class people): the ordination was an expression of rural peoples' love and respect for the forest, Buddhism is a conservationist religion, the animist rituals called the local spirits to help protect the forest, and so on. As I have shown in the analysis of an actual ritual, such representations flatten out significant complexity in the ways participants actually experienced and interpreted the ritual. In a sense, then, the objectifying and generifying process entailed by the ordinations is incomplete.

Even if some complexity of meaning attached to the ordination events survives among people in places like Lay Mun, perhaps what really matters is the way the people of such communities appear to outsiders. At Chambri, Errington and Gewertz (2001) found a tug of war between the complex uniqueness of traditional ritual knowledge and the need for outsiders - like tourists and representatives of the state - to be able to understand and appreciate them. The Chambri found that they had to deal with powerful outsiders, and doing so would mean that "local understandings would either have to be translated into a highly general form or appear to comply with a generic definition of what the "traditional' was like" (Errington and Gewertz 2001:510). While the process of actual simplification among the Chambri themselves was incomplete (i.e. complex and simplified forms and meanings coexisted), Chambri knowledge was made to appear to outsiders not as something unique and valuable, but as an "example of type" - "as a generally plausible manifestation of tradition rather than as an embodiment of immediately grounded truth" (Errington and Gewertz 2001:511). Through a similar process, tree ordinations lead people in Lay Mun and elsewhere to play their stock roles in someone else's drama - as the repositories of local wisdom or as good, king-loving citizens in a script written by NGO workers and monks, to be read by state officials and middle class Thais. An alternative script, authored by rural people themselves, and 
Henry D. Delcore

pressing claims to resources without simplifying the meanings, symbols, and conflicted social relations of rural communities, remains to be written.

Shortly after September 11, 2001, a radio station where I live ran a series of interviews inviting religious leaders to reflect on the religious response to the terrorist attacks. Reflecting on possible Buddhist responses, an American Buddhist leader stated, in part: "The purpose of religion is to provide us with the tools to deal with the negative aspects of our existence." Applying the instrumental language of "tools" that are used to "deal with" life's circumstances is a particularly objectifying and somewhat generifying way of framing religious life. This approach to religion implies a cultural logic whereby the believer displays the ability to step outside of the lived practice of their religion and assert the instrumental value of that religion in solving life's problems. I would argue that this approach to religion is quite widespread in places where the concept of "culture" has become itself a "tool" that people use to perform a kind of anthropological self-analysis. The overt manipulation of Thai religious rituals and symbols in tree ordinations reflects the ongoing objectification of "culture" in the modern world, a world in which "culture" is has become less something unselfconsciously lived, and more something that is selfconsciously held up, evaluated, simplified, and redeployed in political projects. This process is not inherently empowering or disempowering to people engaged in struggles with the powerful for control over resources; what matters are the agencies involved. In the case of tree ordinations, I argue that this objectification of culture is largely a project of some in the Thai middle class, as they seek to find a cultural basis for an environmental agenda. In the process of deploying tree ordinations, middle class NGO activists in effect claim for themselves privileged roles as the arbiters of "good" and "bad" culture in Thailand (Gewertz and Errington 1999 note a similar process in New Guinea; see also Dove 1999:232-233). And not all of what rural people think and do is "good." Ecology monks and NGO activists in Thailand can be heard to complain that rural people "like convenience too much" and so are drawn to the pursuit of motorcycles and refrigerators - often at the expense of the forest, which can be cut and sold or cleared for corn fields and teak plantations. The NGOs' rural constituents, in effect, must submit their traditions for evaluation by the middle class activists, who sort out which traditions are to be kept, which discarded, and which generified in pursuit of political goals.

Acknowledgments: This article is based on fieldwork conducted in Thailand in 1996-1998, with support from a Fulbright-Hays Doctoral Dissertation Research Abroad Fellowship (United States Department of Education) and a Wenner-Gren Foundation Small Grant. Many people in Thailand offered generous support to this research, including Arun Panya, Dr. Chayan Vaddhanaphuti, Phra Khru Phithak Nanthakhun, and Sathaporn Somsak. I would also like to thank Katherine Bowie, Sue Darlington, and Deborah Gewertz for their comments and suggestions on an earlier draft of this article; I am however solely responsible for any shortcomings found here.

\section{Cited References}

Phya Anuman Rajadhon.

1962. The Khwan and Its Ceremonies. Journal of the Siam Society 50(2):119-164.

Bello, Walden, Shea Cunningham, and Li Kheng Poh.

1998. A Siamese Tragedy: Development and Disintegration in Modern Thailand. London: Zed Books.

Bowie, Katherine.

1997. Rituals of National Loyalty: An Anthropology of the State and the Village Scout Movement in Thailand. New York: Columbia University Press.

Brenner, Verena, Reiner Buergin, Christl Kessler, Oliver Pye, Rainer Schwarzmeier, and Rolf-

Dieter Sprung.

1999. Thailand's Community Forest Bill: U-Turn or Roundabout in Forest Policy ? SEFUT Working Paper No. 3, revised edition. Freiburg: Albert-Ludwigs-University Freiburg. 
Symbolic Politics or Generification?

Brosius, J. Peter.

1997. Endangered Forest, Endangered People: Environmentalist Representations of Indigenous Knowledge. Human Ecology 25(1):47-69.

Brosius, J. Peter.

1999. Analyses and Interventions: Anthropological Engagement with Environmentalism. American Anthropologist 40(1):277-309.

Carrere, Ricardo, and Larry Lohmann.

1996. Pulping the South: Industrial Tree Plantations in the World Paper Economy. London: Zed Books.

Cohn, Bernard S.

1987. The Census, Social Structure and Objectification in South Asia. In An Anthropologist Among the Historians and Other Essays. Oxford: Oxford University Press.

Coordinating Committee for Southern NGOs.

2002. Dhamma Yatra: Pilgrimage for Environment, Community, and "Social Space" [online].

Songkhla, Thailand: Coordinating Committee for Southern NGOs, 2002 [cited 16

November 2002]. Available from World Wide Web: (http://www.suanmokkh.org/ds/dy/)

Copeland, Matthew.

1993. Contested Nationalism and the 1932 Overthrow of the Absolute Monarchy in Siam. Ph.D. dissertation, Australian National University.

Darlington, Susan M.

1997. Not Only Preaching: The Work of the Ecology Monk Phrakhru Pitak Nantakhun of Thailand. Forest, Trees and People Newsletter 34:17-19.

Darlington, Susan M.

1998. The Ordination of a Tree: The Buddhist Ecology Movement in Thailand. Ethnology 37(1):1-15.

Darlington, Susan M.

2000. Rethinking Buddhism and Development: The Emergence of Environmentalist Monks in Thailand [online]. Journal of Buddhist Ethics [cited 25 January 2003]. Available from World Wide Web: (http://jbe.gold.ac.uk/7/darlington001.html)

Darlington, Susan M.

2003. Practical Spirituality and Community Forests: Monks, Ritual, and Radical Conservationism in Thailand. In Nature in the Global South: Environmental Projects in South and Southeast Asia. Paul Greenough and Anna Lowenhaupt Tsing, eds. Durham, NC: Duke University Press.

Dearden, Philip.

1995. Development, the Environment and Social Differentiation in Northern Thailand. In Counting the Costs: Economic Growth and Environmental Change in Thailand. Jonathan Rigg, ed. Pp. 111-130. Singapore: Institute of Southeast Asian Studies.

Delcore, Henry D.

2000. Localizing Development: Environment, Agriculture, and Memory in Northern Thailand. Ph.D. dissertation, University of Wisconsin-Madison.

Delcore, Henry D.

2003. Nongovernmental Organizations and the Work of Memory in Northern Thailand. American Ethnologist 30(1):61-84.

Dixon, Chris.

1999. The Thai Economy: Uneven Development and Internationalisation. London: Routledge.

Dove, Michael R.

1999. Writing for, Versus About, the Ethnographic Other: Issues of Engagement and Reflexivity in Working With a Tribal NGO in Indonesia. Identities 6(2-3):225-253.

Eckel, Malcolm David.

1997. Is There a Buddhist Philosophy of Nature. In Buddhism and Ecology: The Interconnection of Dharma and Deeds. Mary Evelyn Tucker and Duncan Ryuken 
Henry D. Delcore

Williams, eds. Pp. 327-349. Cambridge, MA: Center for the Study of World Religions, Harvard University.

Ellen, Roy, and Holly Harris.

2000. Introduction. In Indigenous Environmental Knowledge and Its Transformations: Critical Anthropological Perspectives. Roy Ellen, Peter Parkes, and Alan Bicker, eds. Pp. 1-33. Amsterdam: Harwood.

Errington, Frederick, and Deborah Gewertz.

2001. On the Generification of Culture: From Blow Fish to Melanesian. Journal of the Royal Anthropological Institute 7:509-525.

Gewertz, Deborah B., and Frederick K. Errington.

1991. Twisted Histories, Altered Contexts: Representing the Chambri in a World System. Cambridge: Cambridge University Press.

Gewertz, Deborah B., and Frederick K. Errington.

1999. Emerging Class in Papua New Guinea: The Telling of Difference. Cambridge: Cambridge University Press.

Gray, Christine E.

1991. Hegemonic Images: Language and Silence in the Royal Thai Polity. Man (n.s.) $26(1): 43-65$.

Handler, Richard.

1984. On Sociocultural Discontinuity: Nationalism and Cultural Objectification in Quebec. Current Anthropology 25(1):55-71.

Handler, Richard.

1988. Nationalism and the Politics of Culture in Quebec. Madison, WI: University of Wisconsin Press.

Harris, Ian.

1991. How Environmentalist Is Buddhism ? Religion 21:101-114.

Harris, Ian.

1995. Getting to Grips With Buddhist Environmentalism: A Provisional Typology. Journal of Buddhist Ethics 2:173-190.

Hayami, Yoko.

1997. Internal and External Discourse of Communality, Tradition and Environment: Minority Claims on Forest in the Northern Hills of Thailand. Southeast Asian Studies 35(3):558-579.

Healey, Chris, and Eugene Hunn.

1993. The Current Status of TEK: Papua New Guinea and North America. In Traditional Ecological Knowledge: Wisdom for Sustainable Development. Nancy M. Williams and Graham Baines, eds. Pp. 27-30. Canberra: Centre for Resource and Environmental Studies, Australian National University.

Hewison, Kevin.

1997. The Monarchy and Democratisation. In Political Change in Thailand: Democracy and Participation. Kevin Hewison, ed. Pp. 58-74. London: Routledge.

Hewison, Kevin, and Seri Phongphit.

2001. Village Life: Culture and Transition in Thailand's Northeast. Bangkok: White Lotus Press.

Hirsch, Philip, ed.

1997a. Seeing Forests for Trees: Environment and Environmentalism in Thailand. Chiang Mai, Thailand: Silkworm Books.

Hirsch, Philip.

1997b. Environment and Environmentalism in Thailand: Material and Ideological Bases. In Seeing Forests for Trees: Environment and Environmentalism in Thailand. Philip Hirsch, ed. Pp. 15-36. Chiang Mai, Thailand: Silkworm Books. 
Symbolic Politics or Generification?

Hunn, Eugene.

1993. What Is Traditional Ecological Knowledge ? In Traditional Ecological Knowledge: Wisdom for Sustainable Development. Nancy M. Williams and Graham Baines, eds. Pp. 13-15. Canberra: Centre for Resource and Environmental Studies, Australian National University.

Isager, Lotte, and Soren Ivarsson.

2002. Contesting Landscapes in Thailand: Tree Ordination as Counter-territorialization. Critical Asian Studies 34(3):395-417.

Jackson, Peter A.

1988. Buddhadasa: A Buddhist Thinker for the Modern World. Bangkok: The Siam Society.

Jackson, Peter A.

1997. Withering Centre, Flourishing Margins: Buddhism's Changing Political Roles. In Political Change in Thailand: Democracy and Participation. Kevin Hewison, ed. Pp. 75-93. London: Routledge.

Kalland, Arne.

2000. Indigenous Knowledge: Prospects and Limitations. In Indigenous Environmental Knowledge and Its Transformations: Critical Anthropological Perspectives. Roy Ellen, Peter Parkes, and Alan Bicker, eds. Pp. 319-336. Amsterdam: Harwood.

Karnjariya Sukrung.

1997. The Fight for the Forests. Bangkok Post [online]. Bangkok: The Post Publishing Co., Ltd. [cited 21 January 2003]. Available from World Wide Web: (http:/ /search.bangkokpost.co.th/bkkpost/1997/june1997/bp970619/1906_out1.html)

Kaye, Lincoln.

1990. Of Cabbages and Cultures. Far Eastern Economic Review 150 (13 December 1990):35-37.

Keyes, Charles F.

1987. Thailand: Buddhist Kingdom as Modern Nation-State. Boulder, CO: Westview Press.

Kirsch, A. Thomas.

1977. Complexity in the Thai Religious System: An Interpretation. Journal of Asian Studies 36(2):241-266.

Lewis, Henry T.

1993. Traditional Ecological Knowledge: Some Definitions. In Traditional Ecological Knowledge: Wisdom for Sustainable Development. Nancy M. Williams and Graham Baines, eds. Pp. 8-12. Canberra: Centre for Resource and Environmental Studies, Australian National University.

Li, Tania Murray.

2000. Locating Indigenous Environmental Knowledge in Indonesia. In Indigenous Environmental Knowledge and Its Transformations: Critical Anthropological Perspectives. Roy Ellen, Peter Parkes, and Alan Bicker, eds. Pp. 121-149. Amsterdam: Harwood.

Lohmann, Larry.

1991. Peasants, Plantations and Pulp: The Politics of Eucalyptus in Thailand. Bulletin of Concerned Asian Scholars 23(4).

Missingham, Bruce.

2002. The Village of the Poor Confronts the State: A Geography of Protest in the Assembly of the Poor. Urban Studies 39(9):1647-1663.

Montree Chantawong, Bunthida Kate Sombun, Orawan Koohacharoen, Pinkaew Leungaramsri,

Petchmala Malapetch, Darunee Paisarnpanichkul, Kitti Thungsuro, and Noel Rajesh.

1992. People and Forests of Thailand. In The Future of People and Forests in Thailand After the Logging Ban. Pinkaew Leungaramsri and Noel Rajesh, eds. Pp. 151-196. Bangkok: Project for Ecological Recovery. 
Morell, David, and Chai-anan Samudavanija.

1981. Political Conflict in Thailand: Reform, Reaction, Revolution. Cambridge, MA: Oelgeschlager, Gunn, and Hain.

Morris, Brian.

1987. Anthropological Studies of Religion: An Introductory Text. Cambridge: Cambridge University Press.

Morris, Rosalind C.

2002. Crises of the Modern in Northern Thailand: Ritual, Tradition, and the New Value of Pastness. In Cultural Crisis and Social Memory: Modernity and Identity in Thailand and Laos. Shigeharu Tanabe and Charles F. Keyes, eds. Pp. 68-94. London: Curzon.

Muscat, Robert J.

1994. The Fifth Tiger: A Study of Thai Development Policy. Helsinki: United Nations University Press.

Pasuk Phongpaichit, and Chris Baker.

1998. Thailand's Boom and Bust. Seattle: University of Washington Press.

Peluso, Nancy Lee, and Peter Vandergeest.

2001. Genealogies of the Political Forest and Customary Rights in Indonesia, Malaysia, and Thailand. Journal of Asian Studies 60(3):761-812.

Pinkaew Laungaramsri.

2001. Redefining Nature: Karen Ecological Knowledge and the Challenge of the Modern Conservation Paradigm. Chennai, India: Earthworm Books.

Prasert Trakarnsuphakorn.

1997. The Wisdom of the Karen in Natural Resource Management. In Development or Domestication ?: Indigenous Peoples of Southeast Asia. Don McCaskill and Ken Kempe, eds. Pp. 205-218. Chiang Mai, Thailand: Silkworm Books.

Program for the Community Forest Ordination of 50 Million Trees in Honor of the King's Golden

Jubilee (PCFO).

1996. Buat Paa Ton Nam (Ordaining Watershed Forests). Bangkok: Department of Environmental Quality Promotion.

Quinn, Rapin.

1997. Competition Over Resources and Local Environment: The Role of Thai NGOs. In Seeing Forests for Trees: Environment and Environmentalism in Thailand. Philip Hirsch, ed. Pp. 89-115. Chiang Mai, Thailand: Silkworm Books.

Reynolds, Craig J., ed.

1993. National Identity and Its Defenders: Thailand, 1939-1989. Clayton, Australia: Centre of Southeast Asian Studies, Monash University.

Reynolds, Craig J.

1998. Globalization and Cultural Nationalism in Modern Thailand. In Southeast Asian Identities: Culture and the Politics of Representation in Indonesia, Malaysia, Singapore, and Thailand. Joel S. Kahn, ed. Pp. 115-145. New York: St. Martin's Press.

Reynolds, Frank E.

1977. Civic Religion and National Community in Thailand. Journal of Asian Studies 36(2):267-282.

Rigg, Jonathan, ed.

1995. Counting the Costs: Economic Growth and Environmental Change in Thailand. Singapore: Institute of Southeast Asian Studies.

Rungrawee Chalermsripinyorat.

2002. People Politics in Mediascape: The Assembly of the Poor and Media Contestation in Thailand. Paper presented at the 54th Annual Meeting of the Association for Asian Studies, April 4-7, Washington, DC.

Santita Ganjanapan.

1997. A Comparative Study of Indigenous and Scientific Concepts in Land and Forest 
Symbolic Politics or Generification?

Classification in Northern Thailand. In Seeing Forests for Trees: Environment and Environmentalism in Thailand. Philip Hirsch, ed. Pp. 247-267. Chiang Mai, Thailand: Silkworm Books.

Sillitoe, Paul.

1998. The Development of Indigenous Knowledge: A New Applied Anthropology. Current Anthropology 39(2):223-252.

Sponsel, Leslie E.

1998. The Historical Ecology of Thailand: Increasing Thresholds of Human Environmental Impact from Prehistory to the Present. In Advances in Historical Ecology. William Balee, ed. Pp. 376-404. New York: Columbia University Press.

Sponsel, Leslie E., and Poranee Natadecha-Sponsel.

1993. The Potential Contribution of Buddhism in Developing an Environmental Ethic for the Conservation of Biodiversity. In Ethics, Religion and Biodiversity: Relations Between Conservation and Cultural Values. Lawrence S. Hamilton, ed. Pp. 75-97. Cambridge: The White Horse Press.

Sponsel, Leslie E., and Poranee Natadecha-Sponsel.

1995. The Role of Buddhism in Creating a More Sustainable Society in Thailand. In Counting the Costs: Economic Growth and Environmental Change in Thailand. Jonathan Rigg, ed. Pp. 27-46. Singapore: Institute of Southeast Asian Studies.

Sponsel, Leslie E., and Poranee Natadecha-Sponsel.

1997. A Theoretical Analysis of the Potential Contribution of the Monastic Community in Promoting a Green Society in Thailand. In Buddhism and Ecology: The Interconnection of Dharma and Deeds. Mary Evelyn Tucker and Duncan Ryuken Williams, eds. Pp. 45-68. Cambridge, MA: Center for the Study of World Religions, Harvard University.

Sponsel, Leslie E., and Poranee Natadecha-Sponsel.

2002. Buddhist Views of Nature and the Environment. In Non-Western Views of Nature and the Environment. Helaine Selin, ed. Dordrecht, The Netherlands: Kluwer Academic Press.

Sponsel, Leslie E., Poranee Natadecha-Sponsel, Nukul Ruttanadakul, and Somporn Juntadach.

1998. Sacred and/or Secular Approaches to Biodiversity Conservation in Thailand. Worldviews 2:155-167.

Stanlaw, James, and Bencha Yoddumnern.

1985. Thai Spirits: A Problem in the Study of Folk Classification. In Directions in Cognitive Anthropology. Janet W.D. Dougherty, ed. Pp. 141-159. Urbana, IL: University of Illinois Press.

Streckfuss, David.

1995. Kings in the Age of Nations: The Paradox of Lese-Majeste as Political Crime in Thailand. Comparative Studies in Society and History 37(3):445-475.

Suchira Payulpitack.

1992. Changing Provinces of Concern: A Case Study of the Social Impact of the Buddhadasa Movement. Sojourn 7(1):39-68.

Sulak Sivaraksa.

1990a. A Buddhist Perception of a Desirable Society. In Ethics of Environment and Development: Global Challenge, International Response. J. Ronald Engel and Joan Gibb Engel, eds. Pp. 213-221. Tucson, AZ: University of Arizona Press.

Sulak Sivaraksa.

1990b. Building Trust Through Economic and Social Development and Ecological Balance: A Buddhist Perspective. In Radical Conservatism: Buddhism in the Contemporary World: Articles in Honour of Bhikkhu Buddhadasa's 84th Birthday Anniversary. Pp. 179-198. Bangkok: Thai Inter-Religious Commission for Development and International Network of Engaged Buddhists.

Swearer, Donald K.

1997. The Hermeneutics of Buddhist Ecology in Contemporary Thailand: Buddhadasa and Dhammapitaka. In Buddhism and Ecology: The Interconnection of Dharma and Deeds. 
Henry D. Delcore

Mary Evelyn Tucker and Duncan Ryuken Williams, eds. Pp. 21-44. Cambridge, MA: Center for the Study of World Religions, Harvard University.

Swearer, Donald K.

1998. Buddhism and Ecology: Challenge and Promise. Earth Ethics 10(1)

Swearer, Donald K.

2001. Principles and Poetry, Places and Stories: The Resources of Buddhist Ecology. Daedalus 130(4).

Tambiah, S.J.

1970. Buddhism and the Spirit Cults in Northeast Thailand. Cambridge: Cambridge University Press.

Tambiah, S.J.

1976. World Conquerer and World Renouncer: A Study of Buddhism and Polity in Thailand Against a Historical Background. Cambridge: Cambridge University Press.

Tanabe, Shigeharu, and Charles F. Keyes.

2002. Introduction. In Cultural Crisis and Social Memory: Modernity and Identity in Thailand and Laos. Shigeharu Tanabe and Charles F. Keyes, eds. Pp. 1-39. London: Curzon.

Tannenbaum, Nicola.

2000. Protest, Tree Ordination, and the Changing Context of Political Ritual. Ethnology 39(2):109-127.

Taylor, J.L.

1993. Social Activism and Resistance on the Thai Frontier: The Case of Phra Prajak Khuttajitto. Bulletin of Concerned Asian Scholars 25(2):3-16.

Taylor, J.L.

1997. Thamma-chaat: Activist Monks and Competing Discourses of Nature and Nation in Northeastern Thailand. In Seeing Forests for Trees: Environment and Environmentalism in Thailand. Philip Hirsch, ed. Pp. 37-52. Chiang Mai, Thailand: Silkworm Books.

Tegbaru, Amare.

1997. Forests, Farmers and the State: Environment and Resistance in Northeastern Thailand. Stockholm: Department of Social Anthropology, Stockholm University.

Textor, Robert.

1960. An Inventory of Non-Buddhist Supernatural Objects in a Central Thai Village. Ph.D. dissertation, Cornell University.

Thongchai Winichakul.

2002. Remembering/Silencing the Traumatic Past: The Ambivalent Memories of the October 1976 Massacre in Bangkok. In Cultural Crisis and Social Memory: Modernity and Identity in Thailand and Laos. Shigeharu Tanabe and Charles F. Keyes, eds. Pp. 243-283. Honolulu: University of Hawai'i Press.

Tsing, Anna Lowenhaupt.

1999. Becoming a Tribal Elder, and Other Green Development Fantasies. In Transforming the Indonesian Uplands: Marginality, Power and Production. Tania Murray Li, ed. Pp. 159-200. Amsterdam: Harwood.

Uraiwan Tan-Kim-Yong.

1997. The Karen Culture: A Co-Existence of Two Forest Conservation Systems. In Development or Domestication ?: Indigenous Peoples of Southeast Asia. Don McCaskill and Ken Kempe, eds. Pp. 219-236. Chiang Mai, Thailand: Silkworm Books.

Vandergeest, Peter, and Nancy Lee Peluso.

1995. Territorialization and State Power in Thailand. Theory and Society 24:385-426.

Vella, Walter F.

1978. Chaiyo ! King Vajiravudh and the Development of Thai Nationalism. Honolulu: University of Hawai'i Press.

Watts, Michael J.

2000. Contested Communities, Malignant Markets, and Gilded Governance: Justice, Resource 
Symbolic Politics or Generification?

Extraction, and Conservation in the Tropics. In People, Plants, and Justice: The Politics of Nature Conservation. Charles Zerner, ed. Pp. 21-51. New York: Columbia University Press.

Wilk, Richard.

1995. Learning to be Local in Belize: Global Systems of Common Difference. In Worlds Apart: Modernity Through the Prism of the Local. Daniel Miller. London: Routledge. Wyatt, David K.

1984. Thailand: A Short History. New Haven, CT: Yale University Press.

Zerner, Charles.

1994. Through a Green Lens: The Construction of Customary Environmental Law and Community in Indonesia’s Maluku Islands. Law and Society Review 28(5):1079-1122.

\begin{abstract}
Since the early 1990s, tree ordinations have become an important practice for some Thai environmental activists who seek greater legitimacy for local management and use of natural resources. This paper, explores the political and cultural effects of tree ordinations by applying the concepts of "cultural objectification" and "cultural generification. It argues that recent uses of tree ordinations depend on a process of cultural objectification, facilitating the generification of the ritual and its various components as an example of the larger category of "local wisdom." Significant forms of power difference are implicated in the process. Middle class NGO activists largely controlled the practice and representation of the ritual and its symbols, and tended to objectify and simplify the values and practices of rural people. The tree ordinations of 1996-1997, dedicated to King Rama IX, had the further effect of symbolically bolstering the hierarchical structure of the Thai state and Thai society as a whole - a structure in which local leaders and middle class NGO activists exercise power as arbiters of "good" and "bad" culture among rural people. These are the ambiguous implications to which the title of this article refers: a process of objectification and generification and its place in the reproduction of a hierarchical political and cultural order, together with some decidedly positive outcomes of tree ordinations for the conservation and control of natural resources by rural people.
\end{abstract}

Key words: Thailand, environmental activism, social hierarchy, power, cultural objectification.

\title{
Resumé
}

Depuis le début des années 1990, l'ordination des arbres a été une pratique importante pour les activistes environnementales Thaïes qui cherchent à augmenter la légitimité de l'aménagement local et l'usage local des ressources naturelles. Cet article examine les effets politiques et culturels de l'ordination des arbres à travers l'application des idées de "l'objectification culturelle" et "la générification culturelle." Il propose que les usages récentes de l'ordination des arbres dépendent sur un processus de l'objectification culturelle qui facilite la générification du rituel et ses composantes comme exemple d'une catégorie plus grande de "sagesse locale." Des formes importantes de différence de pouvoir sont impliquées dans ce processus. Des NGOs activistes de la moyenne classe contrôlent la pratique et la représentation du rituel et de ses symboles, et ils ont une tendance d'objection et de simplifier les valeurs et les pratiques du peuple rural. L'ordination des arbres de 1996-1997, dédié au Roi Rama IX, ont eu l'effet additionnel de soutenir la structure hiérarchique de l'état Thaï et de la société Thaie tout court - une structure dans laquelle les chefs locales et les NGOs de la moyenne classe tienne le pouvoir comme les arbitres du "bon" et du "mauvais" en ce qui concerne la culture du peuple rural. Ce sont les implications ambiguës du titre de l'article : un processus de l'objectification et de la générification et sa place dans la reproduction de la hiérarchie politique et de l'ordre culturel, combiné avec quelques résultats bien positifs de l'ordination des arbres en ce qui concerne la conservation et le contrôle des ressources naturelles par le peuple rural.

Mots clefs : Thailand, l'activisme environnemental, la hiérarchie sociale, le pouvoir, l'objectification culturelle. 


\section{Henry D. Delcore}

\section{Resumen}

Desde los años 90 tempranos, ordenaciones del árbol se ha convertido en una práctica importante para algunos activistas ambientales Tailandeses que buscan mayor legitimidad para la gerencia y el uso locales de recursos naturales. Este papel, explora los efectos políticos y culturales de las ordenaciones del árbol aplicando los conceptos del "objectificacion cultural" y del "generificacion cultural." Discute que las aplicaciones recientes de las ordenaciones del árbol dependan de un proceso del objectificacion cultural, facilitando el generificacion del ritual y de sus varios componentes como ejemplo de la categoría más grande de la "sabiduría local." Las formas significativas de diferencia de la energía están implicadas en el proceso. Los activistas del NGO de la clase media controlaron en gran parte la práctica y la representación del ritual y de sus símbolos, y objectivar y simplificar los valores y las prácticas de la gente rural. Las ordenaciones del árbol de 1996-1997, dedicadas a rey Rama IX, tenían el efecto posterior simbólicamente de alentar la estructura jerárquica del estado Tailandés y de la sociedad Tailandesa en su totalidad - una estructura en la cual los líderes locales y los activistas del NGO de la clase media ejercitan energía como árbitros de la "buena" y "mala" cultura entre la gente rural. Éstas son las implicaciones ambiguas a las cuales el título de este artículo se refiere: un proceso del objectificacion y del generificacion y su lugar en la reproducción de una orden política y cultural jerárquica, junto con algunos resultados decididamente positivos de las ordenaciones del árbol para la conservación y el control de recursos naturales de la gente rural.

Palabras claves: Tailandia, activismo ambiental, jerarquía social, energía, objectificacion cultural. 